\title{
Permian Potentiometric Analysis
}

\author{
J. L. Devary
}

September 1983

\section{Prepared for}

the U.S. Department of Energy

Office of Nuclear Waste Isolation

under Contract DE-AC06-76RL0 1830

Pacific Northwest Laboratory

Operated for the U.S. Department of Energy

by Battelle Memorial Institute 


\begin{abstract}
DISCL.AIMER
This report was prepared as an account of work sponsored by an agency of the United States Government. Neither the United States Government nor any agency thereof, nor any of their employees, makes any warranty, express or implied, or assumes any legal liability or responsibility for the accuracy, completeness, or usefulness of any information, apparatus, product, or process disclosed, or represents that its use would not infringe privately owned rights. Reference herein to any specific commercial product, process, or service by trade name, trademark, manufacturer, or otherwise, does not necessarily constitute or imply its endorsement, recommendation, or favoring by the United States Government or any agency thereof. The views and opinions of authors expressed herein do not necessarily state or reflect those of the United States Government or any agency thereof.
\end{abstract}

\author{
PACIFIC NORTHWEST LABORATORY \\ operated by \\ BATTELLE \\ for the \\ UNITED STATES DEPARTMENT OF ENERGY \\ under Contract DE-AC06-76RLO 1830
}


PERMIAN POTENTIOMETRIC ANALYSIS

J. L. Devary

September 1983

Prepared for

the U.S. Department of Energy

Office of Nuclear Waste Isolation under Contract DE-ACO6-76RLO 1830

Pacific Northwest Laboratory

Richland, Washington 99352 


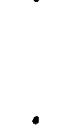

. 


\section{EXECUTIVE SUMMARY}

Pacific Northwest Laboratory (PNL) was requested by the Office of Nuclear Waste Isolation (ONWI) to analyze potentiometric data from the Wolfcamp Formation of the Permian System to evaluate the recommendations by the University of Texas/Bureau of Economic Geology (UT/BEG) that additional geohydrologic boreholes be drilled into the Wolfcamp. The UT/BEG recommended that two stratigraphic and two geohydrologic borings be drilled into the Permian System during FY83 and that several shallow hydrologic tests be made in the Dockum Formation. At PNL, we applied the geostatistical technique known as kriging to objectively evaluate the UT/BEG Wolfcamp geohydrologic borehole recommendations.

The results of our evaluation are:

- The Deaf Smith County location appears to be an excellent choice for a borehole. No high quality potentiometric data are available from Deaf Smith County and a borehole location immediately upgradient from the candidate repository site is needed. Adding this borehole location to the potentiometric data base will significantly reduce field data uncertainty near the location being studied. Also, a simulated head value $300 \mathrm{ft}$ higher than predicted at the borehole location resulted in a $29 \%$ increase in hydraulic gradient along the flow path to the Amarillo Uplift. Thus, a potentiometric value at this Deaf Smith County borehole location could significantly affect contaminant travel time predictions to the Amarillo Uplift.

- The Swisher County location does not appear to be the best choice. High quality data values H2206 and H2360 are located immediately upgradient from the proposed repository site. The standard deviation of the estimation error did not decrease significantly by adding this location to the potentiometric data base. Similarly, we observed no significant difference in head value at the location under investigation when the Swisher County borehole value was simulated $300 \mathrm{ft}$ higher than predicted. 
- The best placement of additional geohydrological boreholes in the Wolfcamp Formation depends strongly upon the proposed repository location. The variability of the potentiometric data causes estimation errors to rapidly increase away from locations of field measurements. For this reason additional boreholes must be located near the proposed repository location and along the travel paths to the Amarillo Uplift. This conclusion is supported by the recent sensitivity-adjoint work by INTERA (Andrews et al. 1982) involving ground-water modeling of the Palo Duro Basin. Suggested locations for additional boreholes for the Deaf Smith investigations (besides the proposed location) are in northwest Randall or central Potter Counties. Ideal borehole locations for the Swisher County studies appear to be in southeast Randall and Armstrong Counties. 


\section{CONTENTS}

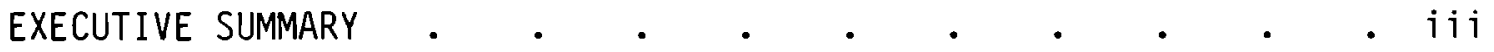

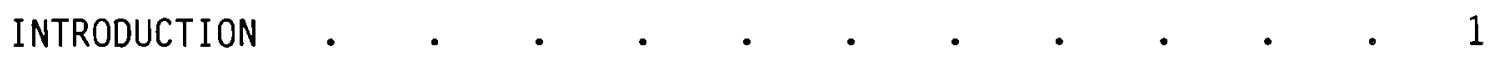

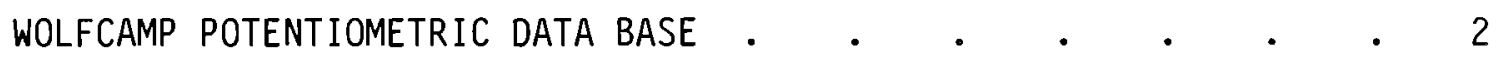

KRIGING ANALYSIS-BEST FIT POTENTIOMETRIC SURFACE • • • • • 9

EVALUATION OF THE UT/BEG WELL LOCATIONS • • • • • • • 17

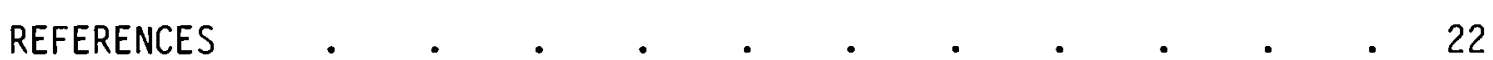

APPENDIX A - WOLFCAMPIAN POTENTIOMETRIC DATA BASE • • • • . A.1 
1 Borehole Locations for the UT/BEG Wolfcamp

Potentiometric Data Base. . • . . . . . 4

2 UT/BEG Interpretation of the Wolfcamp

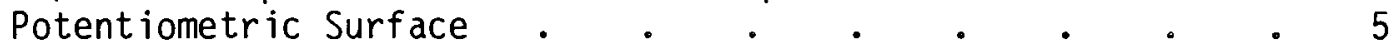

3 Approximate Travel Path from Deaf Smith

County Repository to Amarillo Uplift . . . . . 6

4 Wolfcamp Potentiometric Data Base

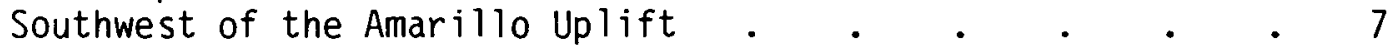

5 The Final Wolfcamp Potentiometric Data

Base Used in the Kriging Analysis . . . . . . 14

6 First Kriged Potentiometric Surface with

Evidence of Significant Measurement Error . . . . 15

$7 \quad$ Kriged Potentiometric Surface Using

$5 \mathrm{mi} \times 5 \mathrm{mi} \mathrm{Block-Average} \mathrm{Data} \mathrm{.} \mathrm{.} \mathrm{.} \mathrm{.} \mathrm{.} \mathrm{.} 17$

8 UT/BEG Wolfcamp Geohydrologic Borehole Location Recommendations . • . . . . . . 20

9 Best-Fit Potentiometric Surface Using $4 \mathrm{mi} \times 5 \mathrm{mi}$ Block-Average Data Without C2746 . . . . . 20

10 Kriging Error Standard Deviation Plot Without Two UT/BEG Boreholes . . . . . . 21

11 Kriging Error Standard Deviation Plot With Two UT/BEG Boreholes . . . . . . . 21

12 Kriged Potentiometric Surface with $1750 \mathrm{ft}$

Kriged Potentiometric Surface with $2725 \mathrm{ft}$
Head Value at Swisher County Borehole . . . . 23

\section{$\underline{\text { TABLES }}$}

1 Wolfcampian Potentiometric Data Base

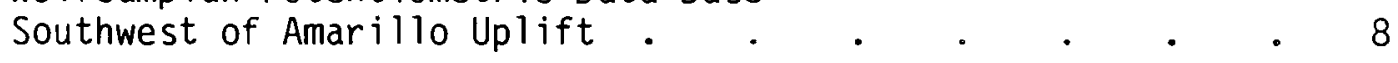

2 Original and Block-Averaged Wolfcamp Potentiometric Values 
The University of Texas/Bureau of Economic Geology (UT/BEG) has recommended that two stratigraphic and two geohydrologic borings be placed in the Permian System during FY83 and that several shallow hydrologic tests be made in the Dockum Formation.(a) Pacific Northwest Laboratory (PNL) was selected by the Office of Nuclear Waste Isolation (ONWI) to analyze potentiometric data from the Wolfcamp formation of the Permian System to evaluate these recommendations. This report satisfies the "Permian potentiometric analysis" milestone of the ONWI Geostatistics Program at PNL.

At PNL, we applied geostatistical data analysis techniques (kriging) to determine whether additional boreholes in Deaf Smith and Swisher Counties will provide a statistically significant amount of additional information. Kriging is a statistical interpolation technique that may be used to estimate a potentiometric surface from irregularly spaced field measurements. The optimal statistical properties of kriging (unbiased, minimum variance) ensures that the maximum amount of information is extracted from the expensive field data. Kriging also allows us to statistically quantify the estimation or interpolation error. This permits us to:

- identify the need for additional field measurements

- select the best borehole locations

- establish data validity

- evaluate measurement error.

We begin this report with an introduction to the Wolfcamp potentiometric data base. This is followed by a discussion of the methods we used in our kriging analysis. Finally, we evaluate the recommended UT/BEG well locations.

(a) This recommendation was made in a letter report, dated October 14, 1982, from E. G. Wermand to Maxwell Blanchard of the Department of Energy, National Waste Terminal Storage (NWTS) Program. 


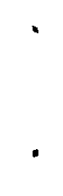




\section{WOLFCAMP POTENTIOMETRIC DATA BASE}

The potentiometric data base for the Wolfcamp Formation was received from UT/BEG late in FY82 by the Assessment and Evaluation of Geologic Isolation Systems (AEGIS) Program of PNL. The data base consists of 274 fluid potential measurements derived from two sources:

- analysis of Horner plots generated from transient pressures changes in drill stem tests (DST).

- pressure data from the Texas Petroleum Institute files.

The Horner analysis values are considered to be the most accurate. The pressure data from the Texas Petroleum Institute are sorted into a hierarchy of reliability levels, based on the criteria below:

- Class $A$ head values are derived from drill stem tests where two shutin periods were recorded for the test and the two final shut-in pressures agreed within $10 \%$.

- Class B head values are derived from drill stem tests where two shutin periods were recorded for the test and the two final shut-in pressures did not agree within 10\%. (In both Class $\mathrm{A}$ and $\mathrm{Cl}$ ass $\mathrm{B}$ the higher pressure was used to calculate heads.)

- Class C head values are derived from drill stem tests where a single shut-in pressure was recorded for the test. As such, we cannot. estimate the accuracy of the head value.

Figure 1 contains a plot of the borehole locations for the Wolfcamp potentiometric data base; a complete listing of the data may be found in Appendix A. Figure 2 is a hand-drawn contour plot corresponding to the UT/BEG interpretation of the Wolfcamp potentiometric data. .

As discussed in the INTERA draft report Status Report on Regional Groundwater Flow Modeling for the Palo Duro Basin, Texas (Andrews et al. 1982), the travel path for a particle released into the Wolfcamp Formation, whether from a repository in east-central Deaf Smith County or in north-central Swisher County, is toward the Amarillo Uplift; the 


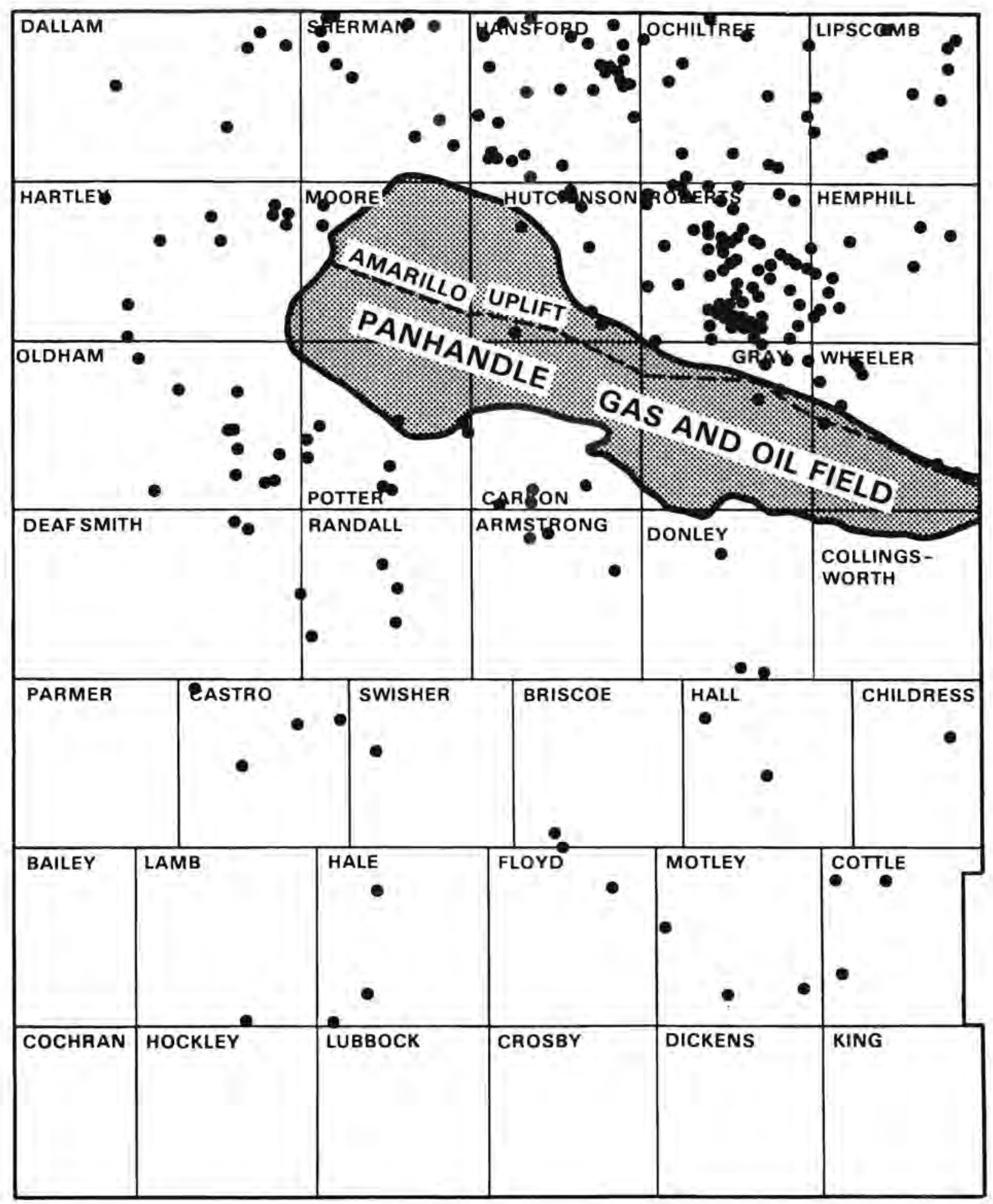

FIGURE 1. Borehole Locations for the UT/BEG Wolfcamp Potentiometric Data Base 


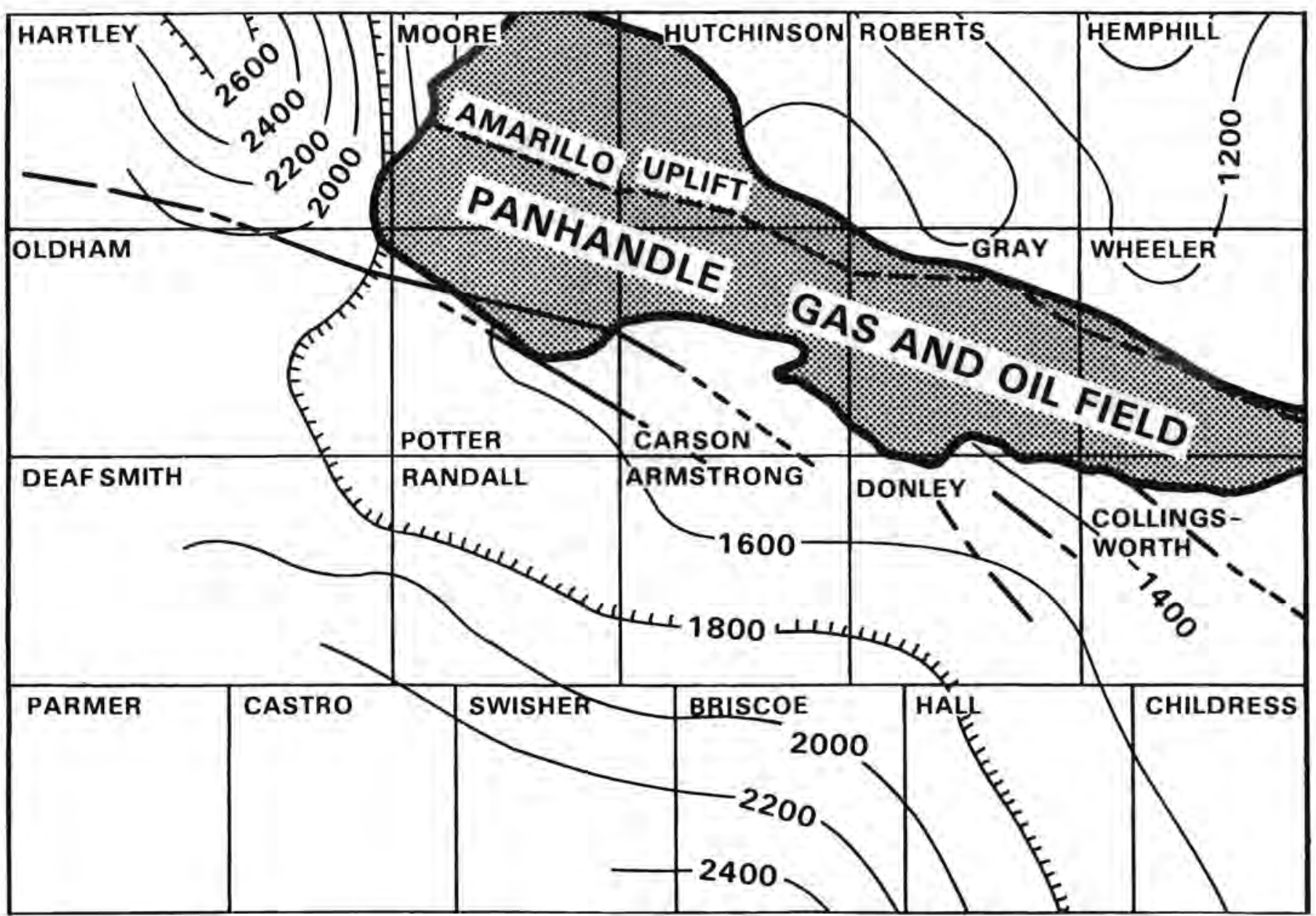

FIGURE 2. UT/BEG Interpretation of the Wolfcamp Potentiometric Surface 
particle presumably continues to the southeast, following the trend of the Amari1lo-Arbuckle Uplift.

The travel time for a particle released into the Wolfcamp Formation from a Deaf Smith repository location to the Panhandle gas and oil field is approximately 4.4 million years (see Figure 3 ). (The head drop is approximately $2000-1500 \mathrm{ft}=213.4 \mathrm{~m}$; hydraulic conductivity is approximately $8.0 \times 10^{-4} \mathrm{~m} / \mathrm{d}$; effective porosity is approximately 0.05 ; travel path length is approximately $74 \mathrm{~km}$.) The travel time for a particle released into the Wolfcamp Formation from a Swisher County repository location would be slightly longer. For this reason we used only the 67 potentiometric data values located southwest of the Amarillo Uplift for our kriging analyses (see Figure 4 and Table 1). The notation used in Figure 4 corresponds to data quality ( $H=$ Horner values; $A=C l$ ass $A$; $B=C 1$ ass $B ; C=C l a s s C$ ) and to potentiometric value (feet); for example, H3597 is a Horner plot head value of $3597 \mathrm{ft}$.

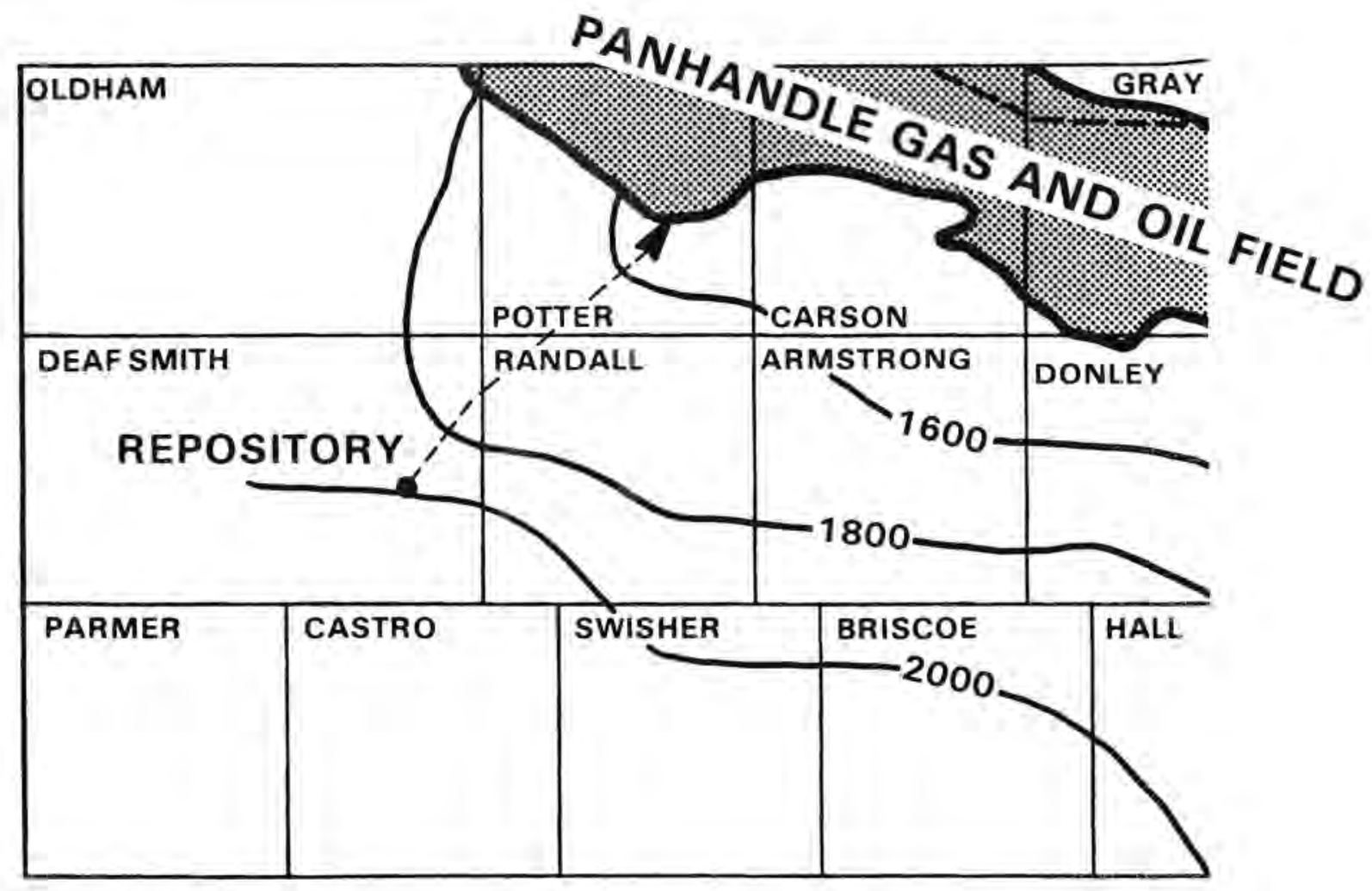

FIGURE 3. Approximate Travel Path from Deaf Smith

Country Repository to Amarillo Uplift 


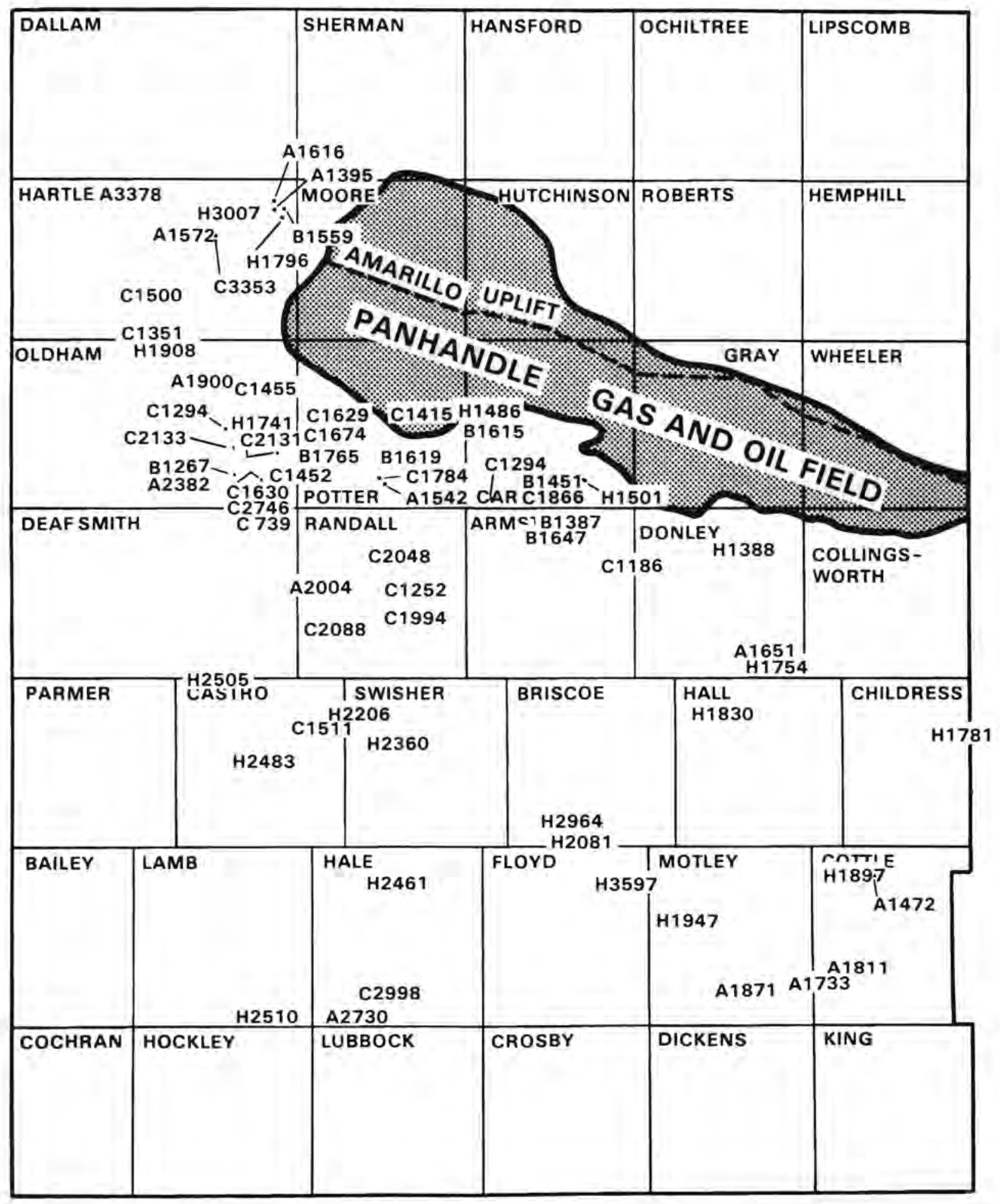

FIGURE 4. Wolfcamp Potentiometric Data Base Southwest of the Amarillo Uplift 
TABLE 1. Wolfcampian Potentiometric Data Base Southwest of Amari110 Up1ift

\begin{tabular}{|c|c|c|c|}
\hline Latitude & Longitude & $\begin{array}{c}\text { Potentiometric } \\
\text { Head }(\mathrm{ft})\end{array}$ & Type \\
\hline 34.21860 & 100.45560 & 1847 & 4 \\
\hline 34.77000 & 100.60000 & 1754 & +1 \\
\hline 35.08000 & 100.81000 & 1334 & $n$ \\
\hline 34.20000 & 101.16000 & 3597 & -4 \\
\hline 34.30365 & 101.31422 & 2081 & $\pi$ \\
\hline 34.19000 & 101.91000 & 2461 & H \\
\hline 34.65000 & 100.56000 & 1030 & 4 \\
\hline 35.96110 & 102.42203 & 3007 & th \\
\hline 35.94376 & 102.19234 & 1790 & $H$ \\
\hline 33.83720 & 102.31500 & 2510 & 4 \\
\hline 34.09330 & 100.90030 & 1947 & $H$ \\
\hline 35.59620 & 102.65120 & 1908 & 4 \\
\hline 35.40704 & 102.34653 & 1741 & is \\
\hline 35.42839 & 101.025018 & 1446 & 14 \\
\hline 34.55616 & 101.90129 & 2360 & 14 \\
\hline 34.34015 & $101.3390 ?$ & 2764 & $H$ \\
\hline 35.25790 & 101.24310 & 1501 & 11 \\
\hline 34.51754 & 102.32644 & 2403 & 4 \\
\hline 34.72496 & 102.48156 & 2505 & h \\
\hline 34.64046 & 102.02041 & 2200 & at \\
\hline 34.54698 & 100.09479 & 1781 & $n$ \\
\hline 35.14560 & 102.31091 & 739 & $c$ \\
\hline 35.10503 & 102.35189 & 2740 & C \\
\hline 33.24300 & 102.04130 & 2730 & $\Delta$ \\
\hline 33.91380 & 101.93300 & 2948 & $\mathrm{C}$ \\
\hline 35.28256 & 102.34347 & $12 \mathrm{~h} 7$ & i \\
\hline 35.35332 & 102.34273 & 2133 & $c$ \\
\hline $35.25 n 30$ & 102.00403 & 2332 & 4 \\
\hline 35.27396 & 102.22845 & 1452 & $\hat{\imath}$ \\
\hline 35.27015 & 102.26120 & 1630 & $c$ \\
\hline 35.51130 & 102.52788 & 1900 & A \\
\hline 35.51189 & 102.34523 & 1455 & $c$ \\
\hline 35.33622 & 102.20307 & 2131 & c \\
\hline 35.40461 & 102.30754 & 979 & c \\
\hline 35.24571 & 101.86000 & 1542 & 4 \\
\hline 35.33357 & 102.12674 & 1705 & 9 \\
\hline 35.43167 & 101.83738 & 1415 & $c$ \\
\hline 35.25933 & 101.65799 & 1784 & C \\
\hline 35.31056 & 101.859121 & 1619 & 8 \\
\hline 35.410 .45 & $102.0828 n$ & 1029 & $c$ \\
\hline 35.37728 & 102.11787 & 1674 & $c$ \\
\hline 34.89558 & 101.84147 & 1994 & $\vec{c}$ \\
\hline 34.86696 & 102.10604 & 20138 & C \\
\hline
\end{tabular}


TABLE 1. Continued

\begin{tabular}{|c|c|c|c|}
\hline Latitude & Longitude & $\begin{array}{c}\text { Potentiometric } \\
\text { Head }(\mathrm{ft})\end{array}$ & Type \\
\hline $34.982 \mathrm{MH}$ & 101.63751 & 1252 & C \\
\hline 35.05146 & 101.88579 & 2048 & C \\
\hline 34.97224 & 102.14640 & 2004 & 4 \\
\hline 35.03562 & 101.14980 & 1106 & C \\
\hline 35.13255 & 101.35767 & 1387 & b \\
\hline 35.12109 & 101.41795 & 1647 & $\ddot{\theta}$ \\
\hline 35.21572 & 101.42005 & 1806 & C \\
\hline 35.20928 & 101.51457 & 1294 & c \\
\hline 35.40112 & 101.61410 & 1615 & $\alpha$ \\
\hline 35.24985 & 101.41274 & 1451 & 3 \\
\hline 34.63043 & 102.15479 & 1511 & $c$ \\
\hline 35.90354 & 102.56322 & 1572 & A \\
\hline 35.97172 & 102.18989 & 1395 & 4 \\
\hline 35.97407 & 102.22813 & 1559 & 1 \\
\hline 35.96828 & 102.22530 & 1616 & 4 \\
\hline 36.01475 & 102.76379 & 3378 & 4 \\
\hline 35.90699 & 102.40475 & 3353 & 6 \\
\hline 35.73735 & 102.58905 & 1500 & C \\
\hline $35.6503 a$ & $102.6879 n$ & 1351 & C \\
\hline 33.96830 & 100.43250 & 1811 & $\Delta$ \\
\hline 34.21551 & 100.29460 & 1472 & a \\
\hline 34.78633 & 100.74978 & 1651 & 4 \\
\hline 33.91190 & 100.76890 & 1871 & 4 \\
\hline 33.93250 & 100.55040 & 1733 & $A$ \\
\hline
\end{tabular}




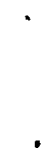

. 


\section{KRIGING ANALYSIS-BEST FIT POTENTIOMETRIC SURFACE}

As mentioned before, kriging is a statistically based interpolator of irregularly spaced data. To krige an estimate of potentiometric head at a particular location where no field measurement is available, the following steps are required:

1. Select the nearest boreholes (with data) for the location to be estimated; typically, between eight and sixteen neighboring boreholes are used in the interpolation procedure.

2. Determine the weights (i.e., the kriging weights) to be used for the averaging process; the kriging weights depend on the drift (overall trend) of the data and the covariance (variogram or generalized covariance) that corresponds to data fluctuations superimposed on the drift.

3. Derive the estimate of potentiometric head by calculating a weighted average of the nearest neighbor values using the kriging weights; the variance and standard deviation corresponding to the estimation error are calculated by using the kriging weights and covariance.

For potentiometric data without evidence of large sources or sinks, the drift is generally constant or is a linear function of the spatial coordinates. The generalized covariance is generally a linear function with a 'nugget' effect, that is,

$$
c_{1}(h)-C_{2}|h|
$$

where $h$ is the distance between two boreholes, (h) is the 'Dirac-delta' function $[(h)=0$ if $h \neq 0,(0)=1]$, and $C_{1}, C_{2}$ are non-negative values. The Dirac-delta or 'nugget' component stems from a measurement error that may be caused by instrument problems or incorrectly surveyed data locations. A full discussion of kriging theory, including drift and generalized covariance estimation may be found in Chiles 1977; Delfiner -1975; Delfiner and Chiles 1978; Delhomme 1976; Gambolati and Volpi 1979; Gelb 1974; Matheron 1965, 1967, 1969, 1973; Mejia 1974; Olea 1975; Volpi and Gambolatti 1978; and Devary and Doctor 1982. 
We screened the 67 potentiometric values (1isted in Table 1) for data validity by calculating a kriging estimate of potentiometric head for each observed data value. The eight nearest neighbors (excluding the observed data value itself) with no drift and a linear generalized covariance (Equation 1 without 'nugget') were used. The true potentiometric head surface is continuous by definition and, therefore, a discontinuous nugget term is not physically realistic. In this way the observed potentiometric value could be compared to the predicted potentiometric value to reveal inconsistencies in the data base. The following potentiometric data values were deleted from the 67-element data base. The $H$ and $A$ data were not scrutinized as closely as the less accurate $B$ and $C$ data; for this reason a significant number of $\mathrm{C}$-values were deleted.

- H3597 -- the only H-value deleted; predicted minus observed equals $-1587 \mathrm{ft}$

- B1267 -- predicted minus observed equals $834 \mathrm{ft}$

- C739 -- predicted minus observed equals $1762 \mathrm{ft}$

- C2998 -- predicted minus observed equals -303 ft; H2510, H2730, H2461 are reliable neighbor values

- C2133 -- predicted minus observed equals $-708 \mathrm{ft}$

- C1452, C1630, C1455 -- predicted minus observed equals 218, -181, $225 \mathrm{ft} ; \mathrm{H} 1741, \mathrm{~A} 1542, \mathrm{~B} 1765$, and $\mathrm{B} 1619$ are more reliable neighbor values

- C2131 -- predicted minus observed equals $-708 \mathrm{ft}$

- $C 979$-- predicted minus observed equals $790 \mathrm{ft}$

- C1252 -- predicted minus observed equals $731 \mathrm{ft}$

- C1866 -- predicted minus observed equals $-424 \mathrm{ft}$

- C1294 -- predicted minus observed equals $425 \mathrm{ft}$

- C1511 -- predicted minus observed equals $807 \mathrm{ft}$

- C3353 -- predicted minus observed equals $-914 \mathrm{ft}$ 
- C1351 -- predicted minus observed equals $384 \mathrm{ft}$

- C1186 - predicted minus observed equals $271 \mathrm{ft}$;

H1500, H1388, A1651 are reliable neighbor values.

The resulting data base of 50 values (Figure 5 ) was used to generate a first kriged potentiometric surface (Figure 6 ). The kriged estimates were generated by using a linear generalized covariance (Equation 1 without 'nugget'), no drift, and eight neighboring values. Notice that the potentiometric contours have a ragged, rough character corresponding to the presence of significant measurement error in the Wolfcamp data. A generalized covariance analysis on the 50 -element data base of Figure 5 found the following best-fit generalized covariance:

$$
8130 \delta(h)-1789|h|
$$

where the distance between boreholes $(h)$ is measured in miles. Equation (2) corresponds to a measurement error of $\pm 90 \mathrm{ft}$, entirely within the error-band of the Permian drill-stem testing program.

To remove this significant measurement error we used a geostatistical technique known as 'block-average' kriging. Block-average kriging involves estimating the average value of potentiometric head over a square block (e.g., 1 mile by 1 mile block) rather than of just a point value. Block-average kriging requires the drift, generalized covariance, and the neighboring values to calculate a weighted average estimate; the only difference between block-average and point kriging is that an integrated covariance is used in the load vector of the kriging equations to determine the block-average kriging weights.

A sequence of block-average head values were kriged (5-10 mi block widths) to select the block width that removed the $\pm 90 \mathrm{ft}$ measurement error, yet did not overly smooth the data. Kriging 5 mile by 5 mile square blocks centered at each observed data value produced a more regular data base resulting in a physically realistic potentiometric surface without evidence of measurement error. A generalized covariance analysis 


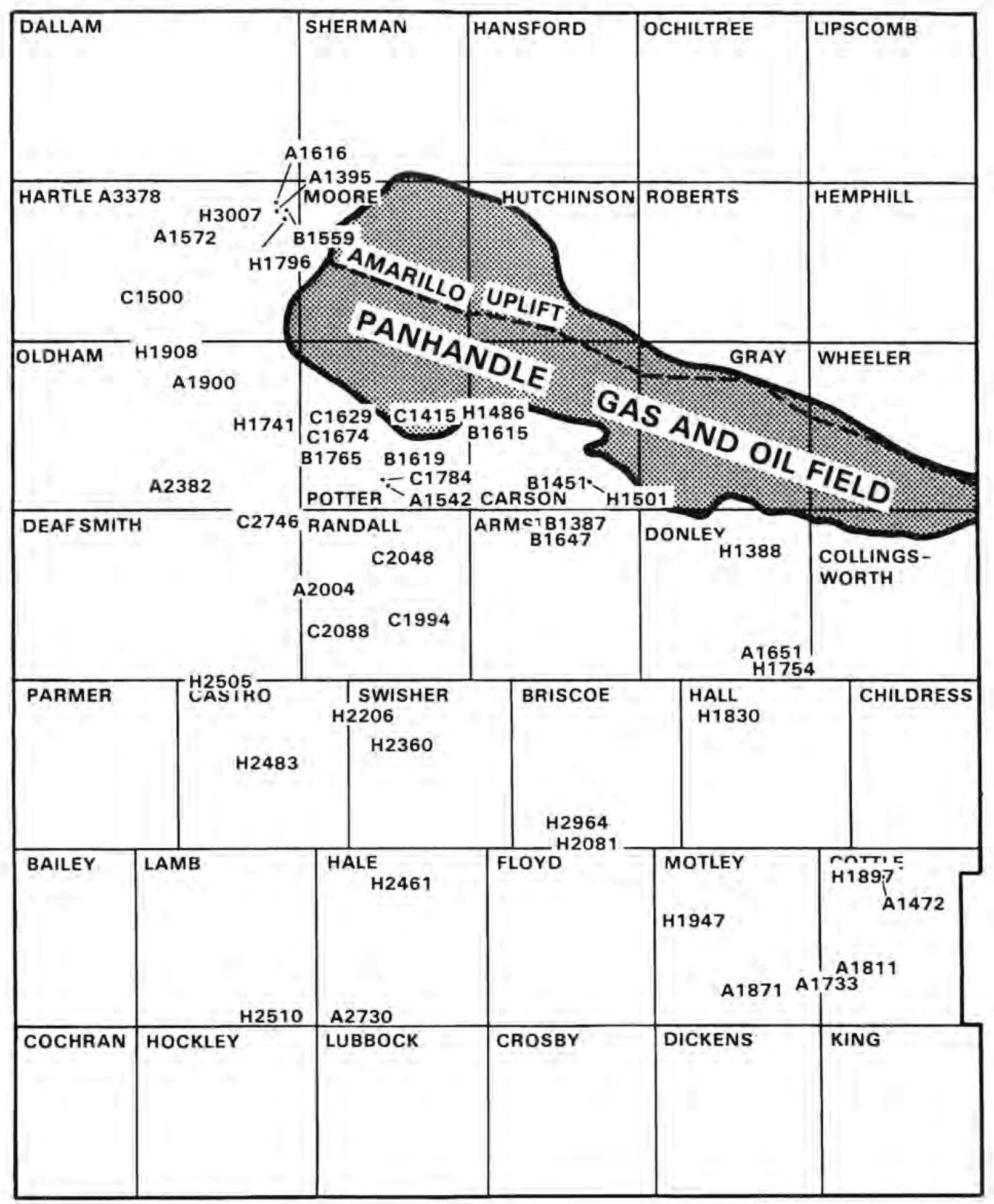

FIGURE 5. The Final Wolfcamp Potentiometric Data Base Used in the Kriging Analysis 


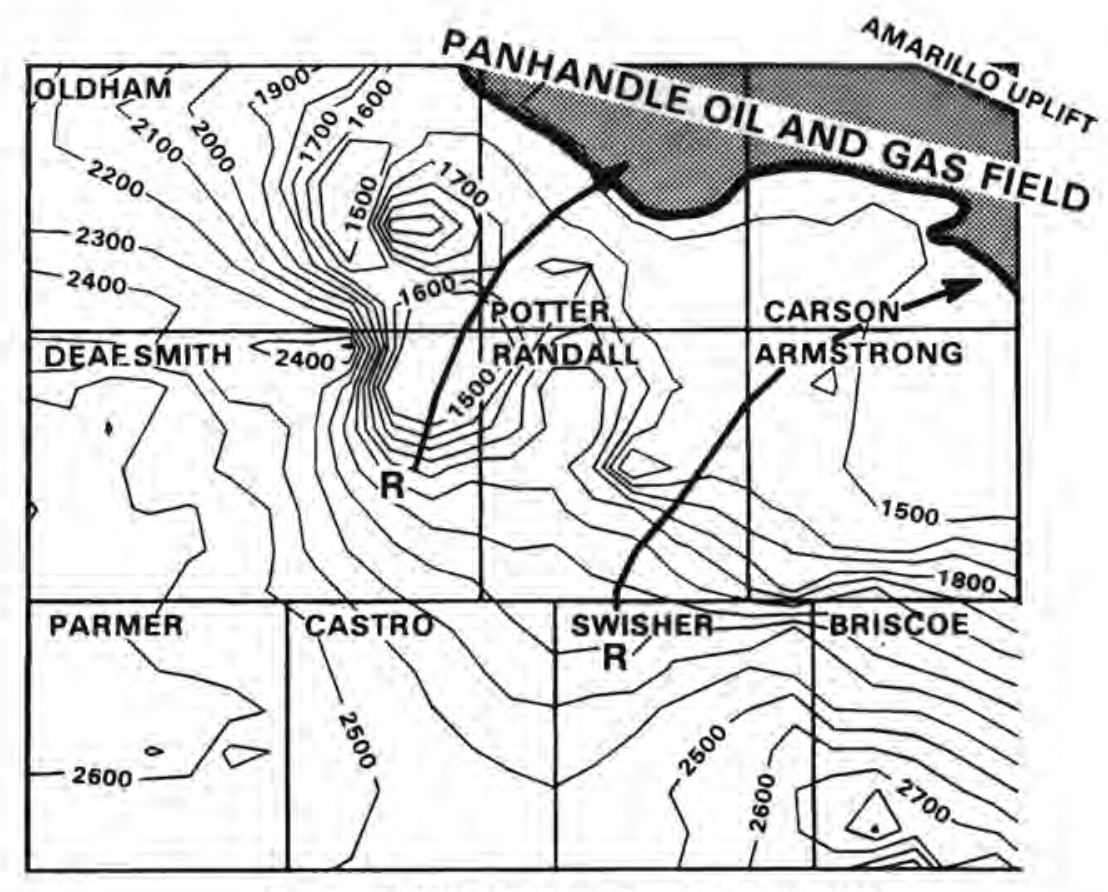

R - APPROXIMATE REPOSITORY LOCATION

FIGURE 6. First Kriged Potentiometric Surface with Evidence of Significant Measurement Error

using the 5 mile by 5 mile block-average data of Table 2 revealed a bestfit generalized covariance:

$$
-1766|h|
$$

Notice that the lack of measurement error 'nugget' and the coefficient on the linear term is not too different from that of Equation (2) -- (-1766 vs. -1789 ). This established that the 5 mile by 5 mile block-average effectively removed the $\pm 90-\mathrm{ft}$ measurement error without oversmoothing the original data. The generalized covariance analysis also revealed that $\mathrm{H} 2081, \mathrm{H} 3007, \mathrm{H} 2964, \mathrm{~A} 1572$, and $\mathrm{A} 3378$, all of which are data values near the Matador Arch or the 01dham Nose, were statistically significant outliers (i.e., the predicted minus observed potentiometric values were over $2.5 \times$ sigma larger than expected). Future analyses involving the Wolfcamp data will have to resolve this unacceptable data variability near these two regions. 
TABLE 2. Original and Block-Averaged Wolfcamp Potentiometric Values

\begin{tabular}{|c|c|c|c|c|c|c|}
\hline $\begin{array}{l}\text { Original } \\
\text { Potentiometric } \\
\text { Value (ft) }\end{array}$ & $\begin{array}{c}5 \mathrm{mi} \times 5 \mathrm{mi} \\
\text { Block Average } \\
\text { Potentiometric } \\
\text { Value (ft) }\end{array}$ & \multicolumn{3}{|c|}{$\begin{array}{c}\text { Difference } \\
(\mathrm{ft})\end{array}$} & \multicolumn{2}{|r|}{ Comments } \\
\hline 1897 & 1858 & 39 & & & & \\
\hline 1754 & 1730 & 24 & & & & \\
\hline 1388 & 1402 & -14 & & & & \\
\hline 2081 & 2283 & -202 & -- & - & located & near Matador Arch \\
\hline 2461 & 2468 & -7 & & & & \\
\hline 1830 & 1838 & -8 & & & & \\
\hline 3007 & 2793 & 214 & -- & - & located & near 01dham Nose \\
\hline 1796 & 1660 & 136 & - & - & Tocated & near 0ldham Nose \\
\hline 2510 & 2524 & -14 & & & & \\
\hline 1947 & 1946 & 1 & & & & \\
\hline 1908 & 1883 & 25 & & & & \\
\hline 1741 & 1778 & -37 & & & & \\
\hline 1486 & 1516 & -30 & & & & \\
\hline 2360 & 2345 & 15 & & & & \\
\hline 2964 & 2730 & 234 & - & - & located & near Matador Arch \\
\hline 1501 & 1484 & 17 & & & & \\
\hline 2483 & 2480 & 3 & & & & \\
\hline 2505 & 2495 & 10 & & & & \\
\hline 2206 & 2221 & -15 & & & & \\
\hline 2730 & 2705 & 25 & & & & \\
\hline 1572 & 1768 & -196 & - & - & Tocated & near 01dham Nose \\
\hline 1395 & 1581 & -186 & - & - & located & near 01dham Nose \\
\hline 1616 & 1676 & -60 & & & & : \\
\hline 3378 & 3255 & 123 & - & - & located & near 01dham Nose \\
\hline 2382 & 2384 & -2 & & & & \\
\hline 1900 & 1894 & 6 & & & & \\
\hline 1542 & 1646 & -104 & -- & - & located & in Potter County \\
\hline 2004 & 2043 & -39 & & & 10 & (2) \\
\hline 1559 & 1694 & -135 & - & - & located & near 0ldham Nose \\
\hline 1765 & 1779 & -14 & & & & 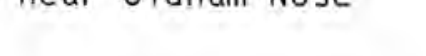 \\
\hline 1619 & 1623 & -4 & & & & \\
\hline 1387 & 1450 & -63 & - & - & located & in Armstrong County \\
\hline 1647 & 1598 & 49 & & & & \\
\hline 1615 & 1561 & 54 & 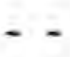 & - & located & in Carson County \\
\hline 1451 & 1470 & -19 & & & & \\
\hline 1811 & 1791 & 20 & & & & \\
\hline 1472 & 1516 & -44 & & & & \\
\hline 1651 & 1670 & -19 & & & & \\
\hline 1871 & 1866 & 5 & & & & \\
\hline 1733 & 1753 & -20 & & & & \\
\hline 2746 & 2657 & 89 & - & - & located & in Deaf Smith County \\
\hline 1500 & 1579 & $-79-$ & - & - & located & near 0ldham Nose \\
\hline 1415 & 1443 & -28 & & & & ment \\
\hline 1784 & 1688 & 96. & - - & - & located & in Potter County \\
\hline 1629 & 1633 & -4 & & & & \\
\hline 1674 & 1687 & -13 & & & & \\
\hline 1994 & 2008 & -14 & & & & \\
\hline 2088 & 2085 & 3 & & & & \\
\hline 2048 & 2014 & 34 & & & & \\
\hline
\end{tabular}


Table 2 contains a list of the original potentiometric values, the block-averaged potentiometric values, and the difference between the two quantities. Notice that the largest differences (greater than $50 \mathrm{ft}$ ) between the original and block-average values occur in regions near the Matador Arch and the 0ldham Nose. These regions contain potentiometric data with high variability (e.g., H2964 and H2081 near the Matador Arch, and $\mathrm{H} 3007$ and $\mathrm{A} 1572$ near the 01 dham Nose).

Figure 7 contains a plot of the kriged potentiometric surface using the 5 mile by 5 mile block-average data, no drift, a linear generalized covariance (Equation 1 without 'nugget'), and eight neighboring points. Notice that this potentiometric surface is quite smooth and regular and is generally similar to the UT/BEG surface (Figure 2). The major differences between this kriged surface and the UT/BEG surface are:

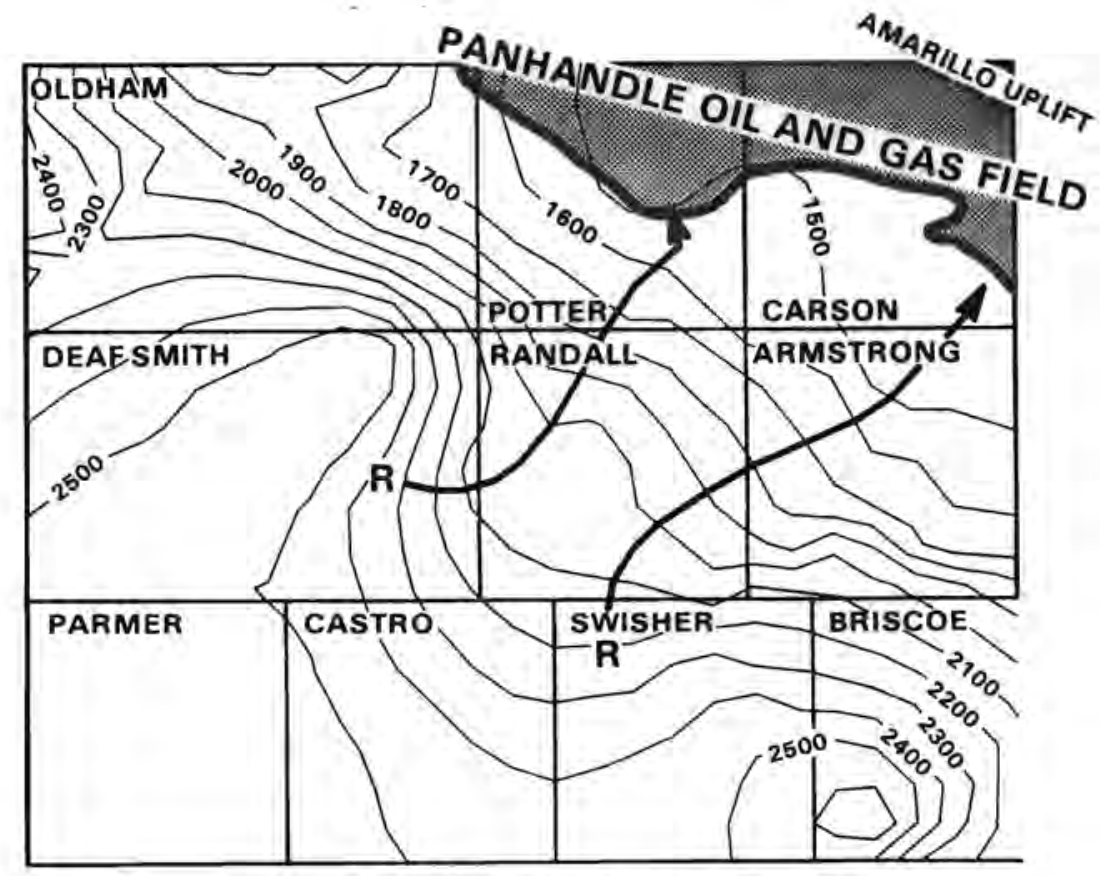

R - APPROXIMATE REPOSITORY LOCATION

FIGURE 7. Kriged Potentiometric Surface Using $5 \mathrm{mi} \times 5 \mathrm{mi}$ Block-Average Data 
- Our inclusion of C2746 in Deaf Smith County causes a high gradient in NE Deaf Smith County; UT/BEG does not include C2746 in their interpretation of the potentiometric surface.

UT/BEG includes C1252 to produce an 1800-ft contour through central Randa11 County; we have deleted $\mathrm{C} 1252$ as being erroneous.

The extreme variability of the potentiometric data near Matador Arch and 01dham Nose precludes kriging the symmetric contours as seen on the UT/BEG surface; this variability does not appear to adversely affect the kriged potentiometric contours in the vicinity of the flow paths from east-central Deaf Smith or north-central Swisher Counties to the Amarillo Uplift. 


\section{EVALUATION OF THE UT/BEG WELL LOCATIONS}

The 5 mile by 5 mile block-average interpretation of the potentiometric data will serve as the basis for our evaluation of UT/BEG's borehole recommendations. The borehole locations that UT/BEG have recommended to NWTS are indicated in Figure 8.

Figure 9 contains a plot of the best-fit kriged potentiometric surface without $\mathrm{C} 2746$, using the 5 mile by 5 mile block-average data, no drift, and generalized covariance, given by

$$
-1766|\mathrm{~h}|
$$

and eight neighboring points. Approximate travel paths from Deaf Smith and Swisher County repository locations are also indicated on Figure 9. The 02746 data value was not used in the borehole evaluation because it was judged to be unreliable and not used in the UT/BEG interpretation of the potentiometric surface (Figure 2) and was also found to be a statistical outlier at the $1.46 \times$ sigma level of significance in the generalized covariance analysis.

Figure 10 contains a contour plot of the standard deviation surface for the kriging error, using the 5 mile by 5 mile block-average data without the two additional UT/BEG boreholes. Notice that the standard deviation is approximately $140 \mathrm{ft}$ at the Deaf Smith County repository Tcoation and approximately $120 \mathrm{ft}$ at the Swisher County location.

Figure 11 contains a contour plot of the kriging error standard deviation using the $5 \mathrm{mile}$ by $5 \mathrm{mile}$ block-average data including the two additional UT/BEG boreholes. As expected, the standard deviations decrease substantially at the proposed borehole locations. The standard deviation at the Deaf Smith repository location has dropped to $120 \mathrm{ft}$, whereas the standard deviation at the Swisher location has remained unchanged at approximately $120 \mathrm{ft}$. This shows that the Swisher County borehole location, as recommended by UT/BEG, has not significantly reduced the field data uncertainty near the Swisher County repository 


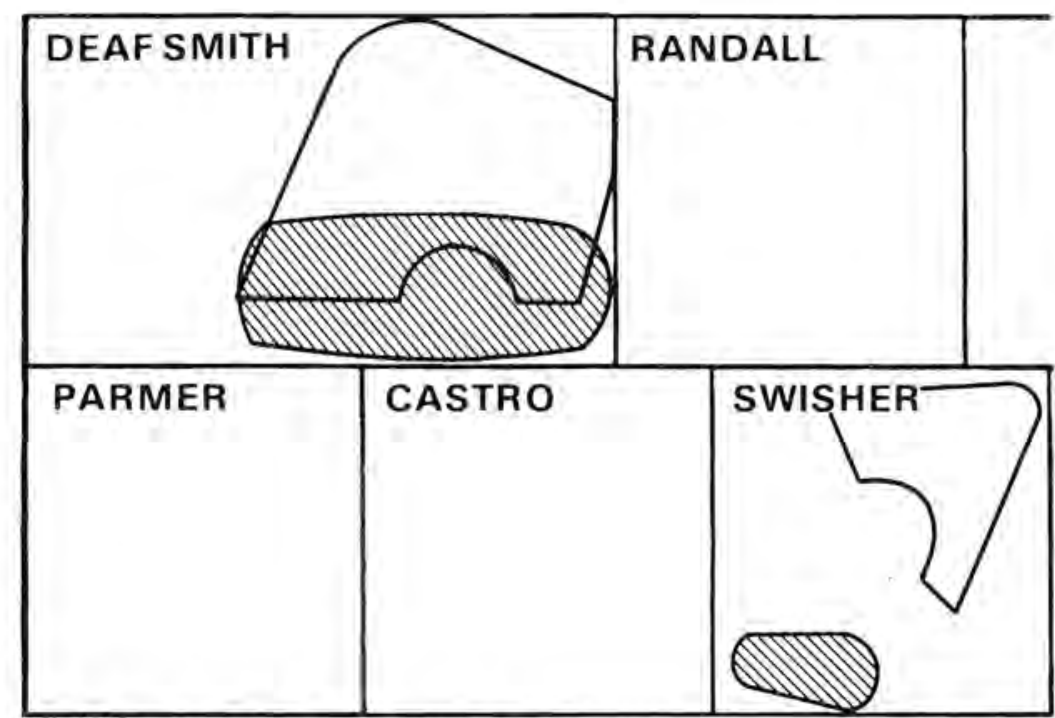

( ) CANDIDATE REPOSITORY LOCATIONS

OOL WOLCAMPIAN BOREHOLE LOCATIONS

FIGURE 8. UT/BEG Wolfcamp Geohydrologic Borehole Location Recommendations

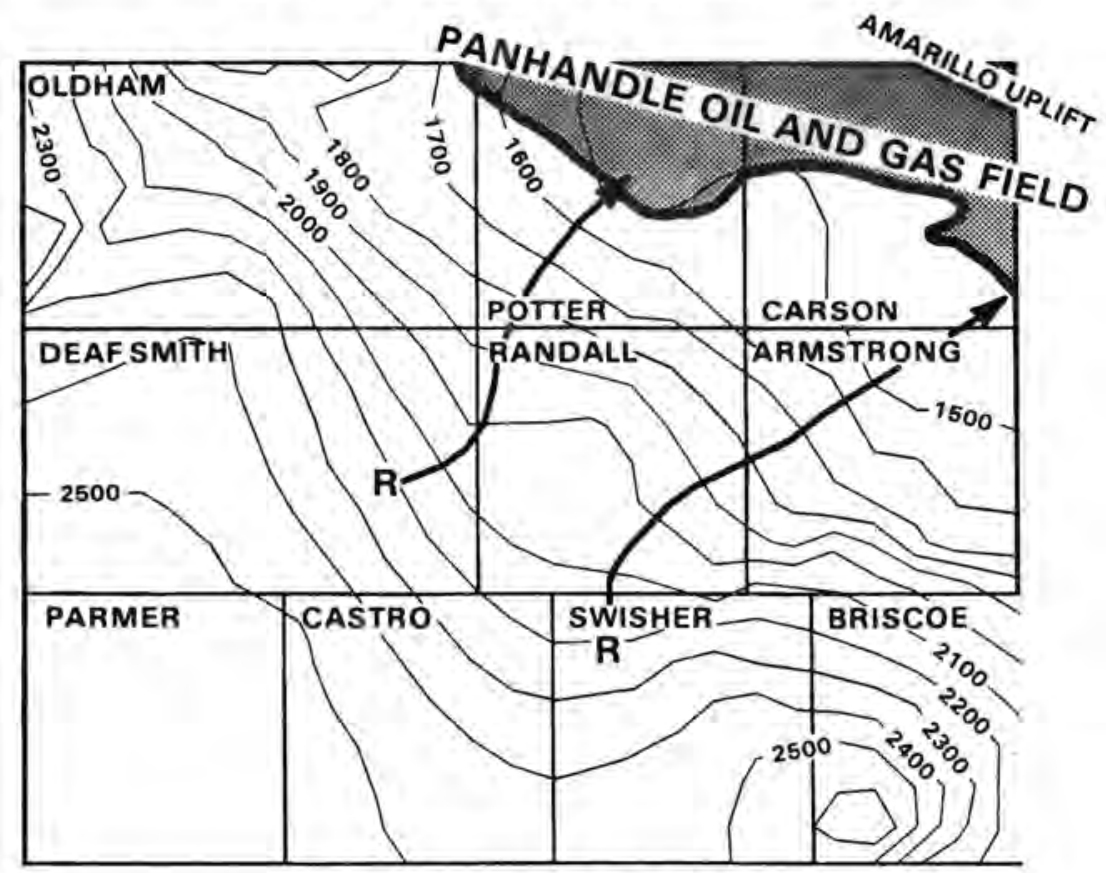

R - APPROXIMATE REPOSITORY LOCATION

FIGURE 9. Best-Fit Potentiometric Surface Using $5 \mathrm{mi} \times 5 \mathrm{mi}$ Block-Average Data Without C2746 


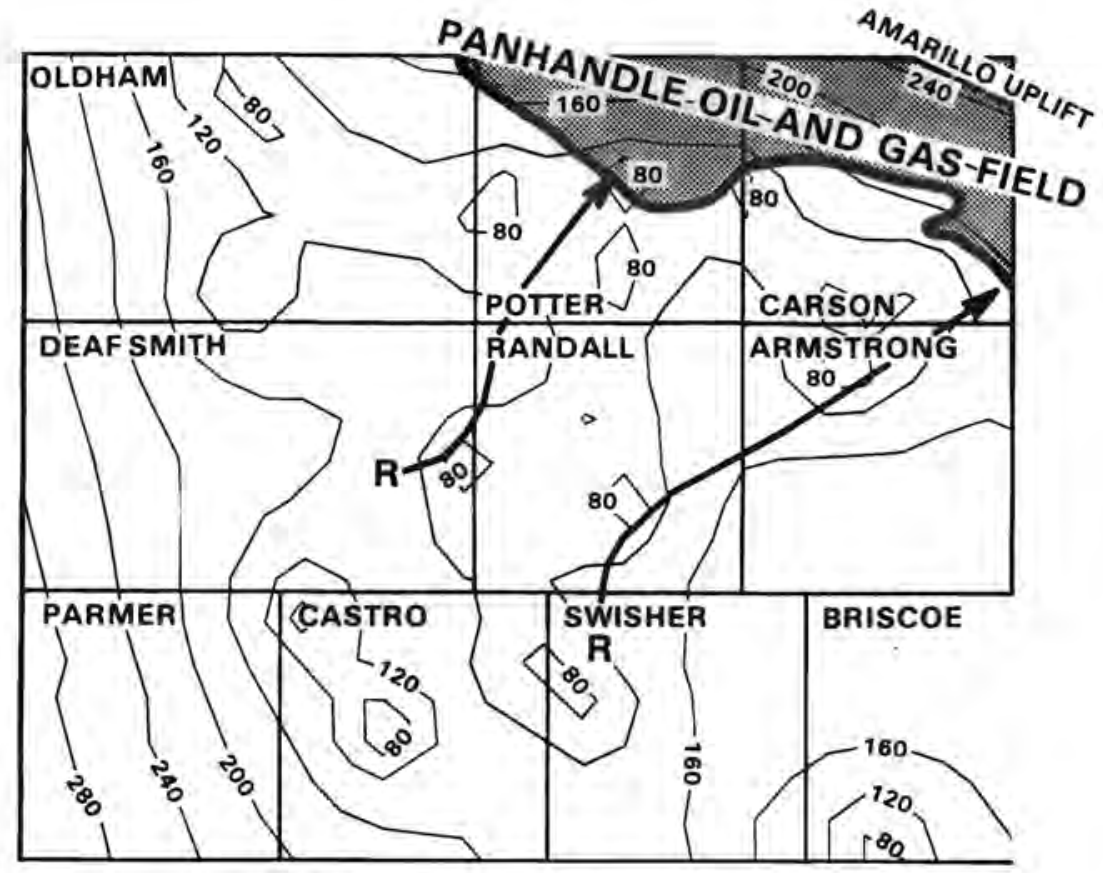

R - APPROXIMATE REPOSITORY LOCATION

FIGURE 10. Kriging Error Standard Deviation Plot Without Two UT/BEG Boreholes

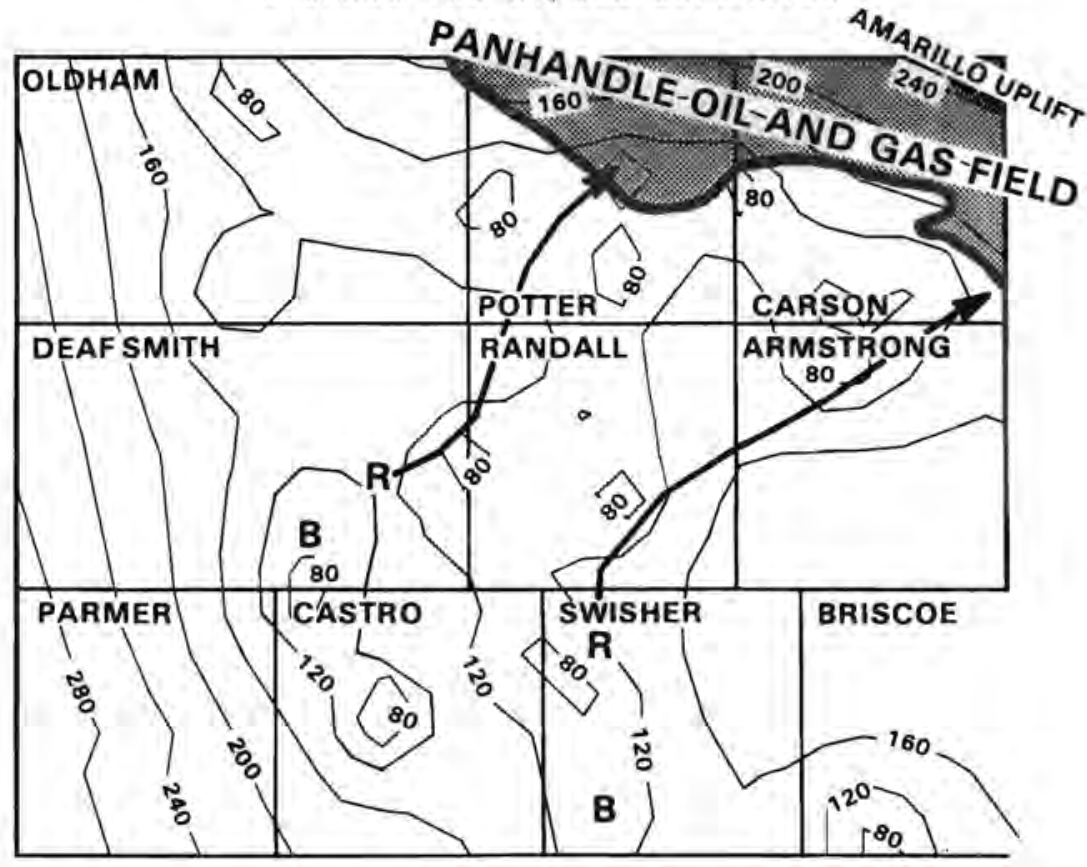

B - BOREHOLE LOCATION

R - APPROXIMATE REPOSITORY LOCATION

FIGURE 11. Kriging Error Standard Deviation Plot With Two UT/BEG Boreholes 
location. The Deaf Smith County borehole location appears to be an excellent choice because the kriging error standard deviation is reduced approximately $20 \mathrm{ft}$ at the repository site.

To further investigate the UT/BEG recommendations, we purposely simulated high potentiometric values for the two proposed borehole locations and added these to the Wolfcamp data base. Figure 12 contains a plot of the kriged surface using the 5 mile by 5 mile block-average data, plus a 2750-ft simulated head value at the Deaf Smith borehole location. (2750 ft is $300 \mathrm{ft}$ (approximately $3 \times$ sigma) higher than predicted.) The Deaf Smith County repository potentiometric value increased $200 \mathrm{ft}$ (compare to Figure 9), resulting in approximately a $29 \%$ increase in hydrautic gradient from Deaf Smith County to the southwestern border of the Amari110 Uplift. This corresponds to a $22 \%$ reduction in travel time.

Figure 13 contains a plot of the kriged surface using the 5 mile by 5 mile block-average data, plus a 2725 -ft simulated head value at the Swisher County borehole (approximately $300 \mathrm{ft}$ higher than expected). The Swisher County repository location potentiometric value does not change appreciably and does not cause any significant change in the flow path or travel time. Thus, the Swisher County borehole Tocation does not appear to be able to can add a significant amount of information to the Wolfcamp data base. 


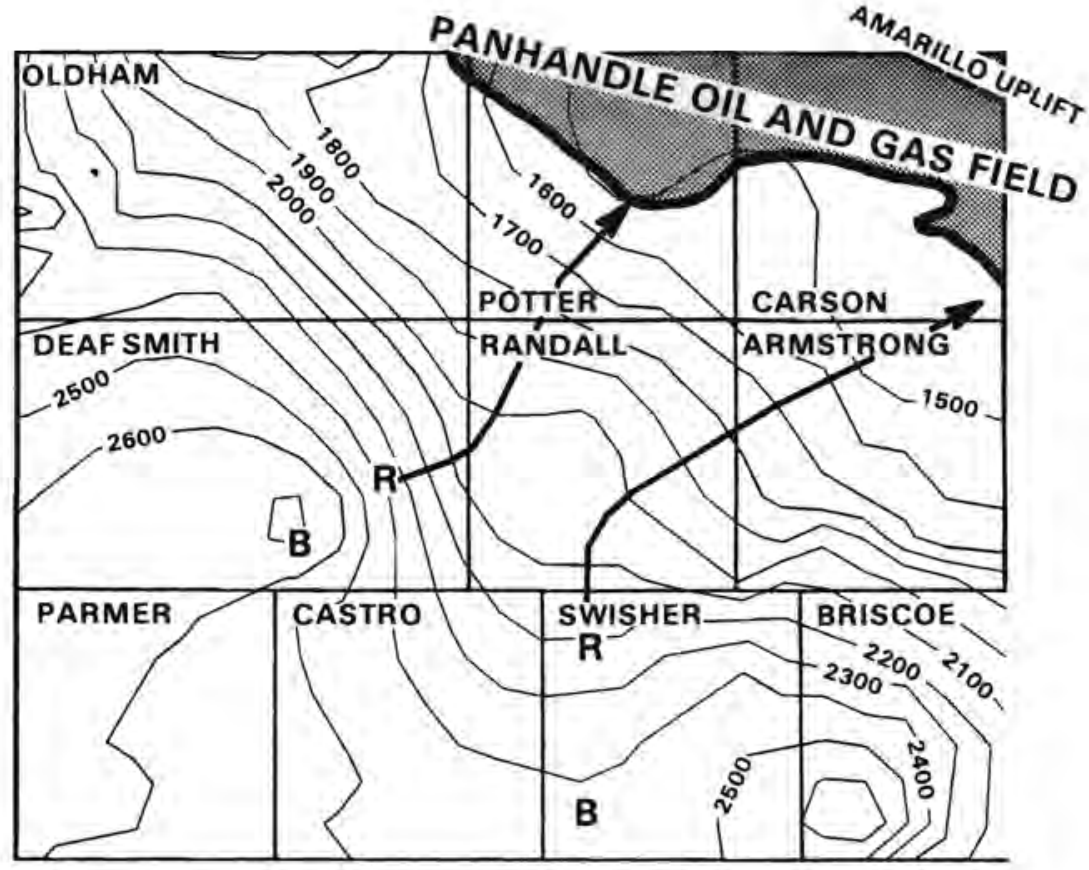

B - BOREHOLE LOCATION

R - APPROXIMATE REPOSITORY LOCATION

FIGURE 12. Kriged Potentiometric Surface with $2750 \mathrm{ft}$ Head Value at Deaf Smith Borehole

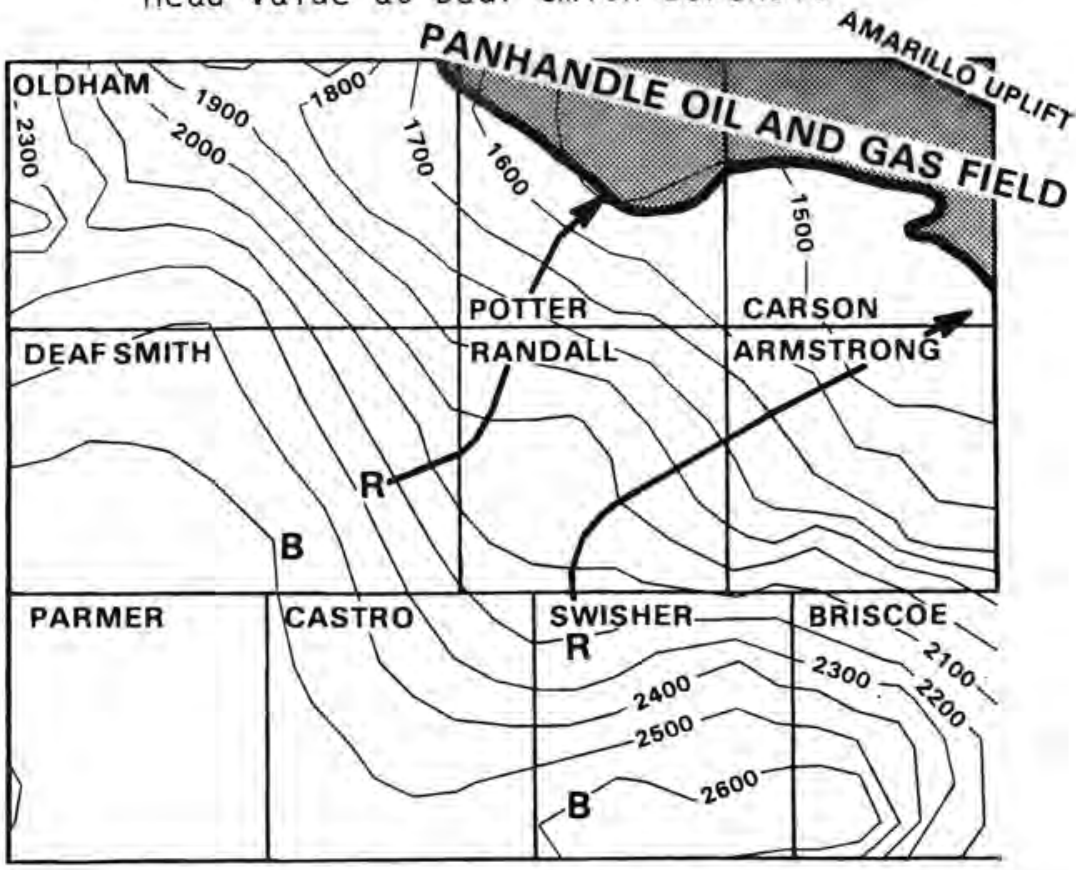

B - BOREHOLE LOCATION

R - APPROXIMATE REPOSITORY LOCATION

FIGURE 13. Kriged Potentiometric Surface with $2725 \mathrm{ft}$ Head Value at Swisher County Borehole 


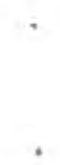




\section{REFERENCES}

Andrews, R. W., et al. 1982. Status Report on Regional Groundwater Flow Modeling for the Palo Duro Basin, Texas, ONWI/E512-02900/TR-13 A1OAO0G-03.

Chiles, J. P. 1977. Geostatistique des Phenomenes Non Stationnaires (in French). The se de Docteur-Ingenieur, University de Nancy, Nancy, France.

Delfiner, P. 1975. "Linear Estimation of Non-Stationary Phenomena." In Advance Geostatistics in the Mining Industry, pp. 49-68, Reidel, Dordrecht, Holland.

Delfiner, P., and J. P. Chiles. 1978. "Conditional Simulations: A New Monte Carlo Approach to Probabilistic Evaluation of Hydrocarbon in Place." Ecole des Mines de Paris, Fontainbleu, France.

Delhomme, J. P. 1976. Application of the Theory of Regionalized Variables to the Hydrologic Sciences. Doctoral Dissertation, Ecole des Mines, de Paris, Fontainbleu, France.

Devary, J. L., and P. G. Doctor. 1982. "Pore Velocity Estimation Uncertainties." Water Resources Research 18(4):1157-1164.

Gambolati, G., and G. Volpi. 1979. "Groundwater Contour Mapping in Venice by Stochastic Interpolators. 1. Theory." Water Resources Research 15(2):281-290.

Gelb, A. 1974. Applied Optimal Estimation. M.I.T. Press, Cambridge, Massachusetts.

Hughes, J. P., and D. P. Lettenmaier. 1980. "Aquatic Monitoring: Data Analysis and Network Design Using Regionalized Variable Theory." Department of Civil Engineering, University of Washington, Seattle, Washington.

Matheron, G. 1965. Les Variables Regionalissees et leur Estimation. Masson and Cie, France.

Matheron, G. 1967. Elements pour une Theorie des Milieux Poreus. Masson and Cie, France.

Matheron, G. 1969. "Lew Krigeage Universel." Les Cashiers du CMM; fasc. 1. Fontainbleu, France.

Matheron, G. "The Theory of Regionalized Variables and its Applications." Les Cashiers du CMM; fasc. 5. Fontainbleu, France. 
Matheron, G. 1973. "The Intrinsic Random Functions and Their Applications." Adv. in Applied Probability 5:439-468.

Mejia, J. M. 1974. "On the Synthesis of Random Field Sampling from the Spectrum: An Application to the Generation of Hydrologic Spatial Processes." Water Resources Research 10(4):705-711.

Olea, R. A. 1975. "Optimum Mapping Techniques Using Regionalized Variable Theory." Kansas Geological Society.

Volpi, G., and G. Gambolati. 1978. "On the Use of a Main Trend for the Kriging Technique in Hydrology." Advances in Water Resources $1(6): 345-349$. 
APPENDIX A

WOLFCAMPIAN POTENTIOMETRIC DATA BASE 
APPENDIX A

Wolfcampian Potentiometric Data Base

\begin{tabular}{|c|c|c|c|}
\hline Latitude & Long itude & $\begin{array}{c}\text { Potentiometric } \\
\text { Head }(\mathrm{ft})\end{array}$ & Type \\
\hline 34.21560 & 100.45500 & 1997 & $H$ \\
\hline 33.90830 & 100.43250 & 1311 & $A$ \\
\hline 34.21551 & 100.29000 & 1472 & $A$ \\
\hline 36.20173 & 102.37371 & 1571 & $c$ \\
\hline 36.30941 & 102.72210 & 2528 & C \\
\hline $36.40 \times 67$ & 102.30734 & 2282 & C \\
\hline 36.45301 & 102.20685 & 2000 & C \\
\hline 36.41433 & 102.10723 & 1443 & C \\
\hline 36.40859 & 102.30755 & 2242 & c \\
\hline 35.14560 & 102.31091 & 759 & C \\
\hline 35.10503 & 102.35189 & 2740 & C \\
\hline 34.78633 & 100.74774 & 1051 & a \\
\hline 34.77000 & 100.60000 & 1754 & H \\
\hline 35.08000 & 100.81000 & 1348 & $r$ \\
\hline 34.20000 & 101.16000 & 3597 & 1 \\
\hline 34.30365 & 101.31422 & 2001 & 4 \\
\hline 35.50600 & 100.52405 & 1140 & 4 \\
\hline 35.59541 & 100.501065 & 1123 & $\Delta$ \\
\hline 35.57972 & 100.67169 & 1220 & $c$ \\
\hline 35.59500 & 100.61391 & 1130 & C \\
\hline 35.49005 & 100.69730 & 1695 & $c$ \\
\hline 33.54300 & 102.04130 & 2730 & $\Delta$ \\
\hline 34.19000 & 101.91000 & 2461 & 14 \\
\hline 33.91380 & 101.93360 & 2996 & c \\
\hline 34.65000 & 100.50000 & $\operatorname{los} 5$ & 14 \\
\hline 34.49970 & 100.60030 & 1762 & $c$ \\
\hline 36.13098 & 101.43080 & 1300 & 9 \\
\hline 36.36296 & 101.54537 & 1675 & 0 \\
\hline 36.21361 & 101.51638 & 1013 & i \\
\hline 36.30430 & 101.31719 & 1091 & C \\
\hline 36.35241 & 101.19113 & $13 \times 0$ & $C$ \\
\hline 36.12373 & 101.52121 & 1055 & $r$ \\
\hline 36.49331 & 101.42595 & 1419 & $c$ \\
\hline 36.44083 & 101.28144 & 1139 & $c$ \\
\hline 30.23200 & 101.00719 & 1190 & c \\
\hline 30.42341 & 101.11976 & 1135 & $E$ \\
\hline 36.47434 & 101.15192 & 1072 & $c$ \\
\hline 36.12340 & 101.54384 & 1179 & $A$ \\
\hline 30.30458 & 101.21312 & 1319 & $c$ \\
\hline 30.07010 & 101.42019 & 1734 & C \\
\hline 36.10403 & 101.31078 & 1199 & $A$ \\
\hline 36.11195 & 101.47715 & 1301 & $c$ \\
\hline
\end{tabular}




\section{APPENDIX A - continued}

\begin{tabular}{|c|c|c|c|}
\hline Lat itude & Longitude & $\begin{array}{l}\text { Potentiometric } \\
\text { Head ( ft) } \\
\end{array}$ & Type \\
\hline 36.14223 & $101.5303 \mathrm{~s}$ & 1042 & $\Delta$ \\
\hline 36.47075 & $101.5090 \mathrm{H}$ & 1312 & A \\
\hline 36.42593 & 11)1.23300 & 1228 & c \\
\hline 36.23599 & 101.58920 & $11 \times 3$ & $A$ \\
\hline 36.36712 & 101.19170 & $1+10$ & c \\
\hline $36.2963 \mu$ & 101.42740 & 1017 & C \\
\hline 36.23584 & 101.58023 & 1143 & A \\
\hline 36.44209 & 101.50237 & 1617 & $\dot{4}$ \\
\hline 36.31615 & 101.12617 & 1152 & $c$ \\
\hline 36.33019 & 101.13055 & 1190 & $c$ \\
\hline 36.35497 & 101.14577 & 478 & C \\
\hline 36.37937 & 101.12147 & 1503 & $c$ \\
\hline 36.36027 & 101.17430 & 8115 & $c$ \\
\hline 36.31793 & 101.10510 & 952 & $c$ \\
\hline 35.96110 & 102.42253 & 3007 & $\pi$ \\
\hline 35.90354 & 102.58322 & 1512 & $A$ \\
\hline 35.97172 & 102.18939 & $13+5$ & $A$ \\
\hline 35.97407 & 102.22013 & 1557 & $d$ \\
\hline $35.98 \mathrm{A28}$ & $102.2263 x$ & 1010 & $\Delta$ \\
\hline 35.94076 & 102.19234 & 1790 & $\$$ \\
\hline 36.01475 & 102.70370 & 3373 & $A$ \\
\hline 35.90099 & $102.40+15$ & 3353 & $c$ \\
\hline 35.73735 & $102.6 \times 305$ & 1500 & $c$ \\
\hline 35.05634 & $102.6874 \mathrm{H}$ & 1351 & C \\
\hline 35.707 .2 & $100.520 \times 5$ & 14 is & $A$ \\
\hline 35.74101 & 1010.18401 & 1521 & $A$ \\
\hline 35.08030 & 100.53277 & 1473 & $\Rightarrow$ \\
\hline 35.81050 & 100.40059 & 1541 & 4 \\
\hline 35.72306 & 100.50709 & 1104 & C \\
\hline 35.91894 & 100.09302 & 020 & $c$ \\
\hline 35.72940 & 100.44110 & 1335 & $A$ \\
\hline 35.82124 & 100.52258 & 1066 & 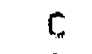 \\
\hline 35.76475 & 100.46840 & $110 y$ & C \\
\hline 35.84502 & 100.20500 & 950 & $c$ \\
\hline $35.9093 \mathrm{~A}$ & 1100.40805 & 1627 & $j$ \\
\hline 35.64703 & 101.18255 & $61) 2$ & a \\
\hline 35.93407 & 101.43975 & 920 & A \\
\hline 36.03431 & 101.30324 & 1316 & $\mathrm{C}$ \\
\hline 35.66456 & 101.40030 & 980 & $\mathrm{C}$ \\
\hline 03924 & 101.28730 & 1334 & $c$ \\
\hline 02981 & 101.23515 & 1345 & $C$ \\
\hline 35.994 .9 & 101.254 .2 & 1010 & $A$ \\
\hline .89259 & 101.22404 & 1350 & $i$ \\
\hline 70788 & 101.20505 & 803 & $\ddot{c}$ \\
\hline 43720 & 102.31530 & 2510 & n \\
\hline
\end{tabular}




\section{APPENDIX A - continued}

\begin{tabular}{|c|c|c|c|}
\hline Latitude & Lcngitude & $\begin{array}{c}\text { Potentiometric } \\
\text { Head }(\mathrm{ft}) \\
\end{array}$ & Type \\
\hline 36.23574 & 100.53683 & 1404 & $\Delta$ \\
\hline $36.12+79$ & 100.33631 & $1+43$ & $\Delta$ \\
\hline 36.35863 & 100.09761 & 1135 & c \\
\hline 36.410 .43 & $100.092 \mathrm{ng}$ & 1235 & $C$ \\
\hline 36.43108 & 100.07940 & 1402 & $c$ \\
\hline 36.29325 & 100.21100 & 1347 & C \\
\hline 30.40310 & 100.29490 & 1145 & C \\
\hline 36.42428 & 100.53675 & 1248 & 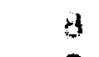 \\
\hline 36.27798 & 100.12532 & 2432 & $c$ \\
\hline 36.28644 & $100.51+42$ & 1020 & C \\
\hline 36.13570 & 100.30514 & 1013 & c \\
\hline 36.19241 & 100.51854 & 1629 & c \\
\hline 35.94563 & 102.07782 & 1585 & $C$ \\
\hline 30.00307 & 102.07500 & 1407 & 6 \\
\hline 36.010399 & 102.07070 & 1408 & c \\
\hline 34.09330 & 100.99030 & 1947 & 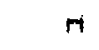 \\
\hline 33.91190 & 100.76890 & 1871 & $A$ \\
\hline 33.73250 & 100.55040 & 1733 & $A$ \\
\hline 30.29173 & 100.60960 & 1466 & $A$ \\
\hline 36.44604 & $100.72 \times 96$ & 1201 & $\Delta$ \\
\hline 30.00897 & 100.92565 & 1105 & c. \\
\hline 30.37320 & 100.940 .9 & 1329 & $c$ \\
\hline 36.10752 & 100.46398 & 1422 & $\mathrm{C}$ \\
\hline 36.49225 & 100.84034 & 1026 & C \\
\hline $36 .+3: 1$ & 101.05900 & 1579 & $a$ \\
\hline $36.1+056$ & 100.04360 & 910 & $c$ \\
\hline 36.10207 & 100.64020 & 1219 & C \\
\hline 36.13303 & 100.77241 & 1081 & C \\
\hline 36.32857 & 100.97809 & 1280 & $c$ \\
\hline 36.06356 & 100.92570 & 1105 & C \\
\hline 35.59020 & 102.65120 & 1908 & $M$ \\
\hline 35.28256 & 102.30341 & 1207 & ; \\
\hline 35.40704 & 102.34653 & 1741 & $H$ \\
\hline 35.35332 & 102.34275 & 2133 & $\mathrm{C}$ \\
\hline 35.24830 & 102.00463 & $23 \times 2$ & $A$ \\
\hline 35.27396 & $102.2 \cos 45$ & 1452 & C \\
\hline 35.27015 & 102.26120 & 1630 & C \\
\hline 35.51130 & 1) 2.527 A & 1900 & $\Delta$ \\
\hline 35.51189 & 102.34523 & 1455 & C \\
\hline 35.33622 & 102.20307 & 2131 & $\mathrm{C}$ \\
\hline 35.40401 & 102.36750 & 979 & C \\
\hline 35.24871 & 101.00406 & 1542 & $A$ \\
\hline 35.42839 & 101.02503 & 1140 & 4 \\
\hline 35.33357 & 102.12074 & 1765 & as \\
\hline 35.43167 & 101.83730 & 1415 & c \\
\hline
\end{tabular}




\section{APPENDIX A - continued}

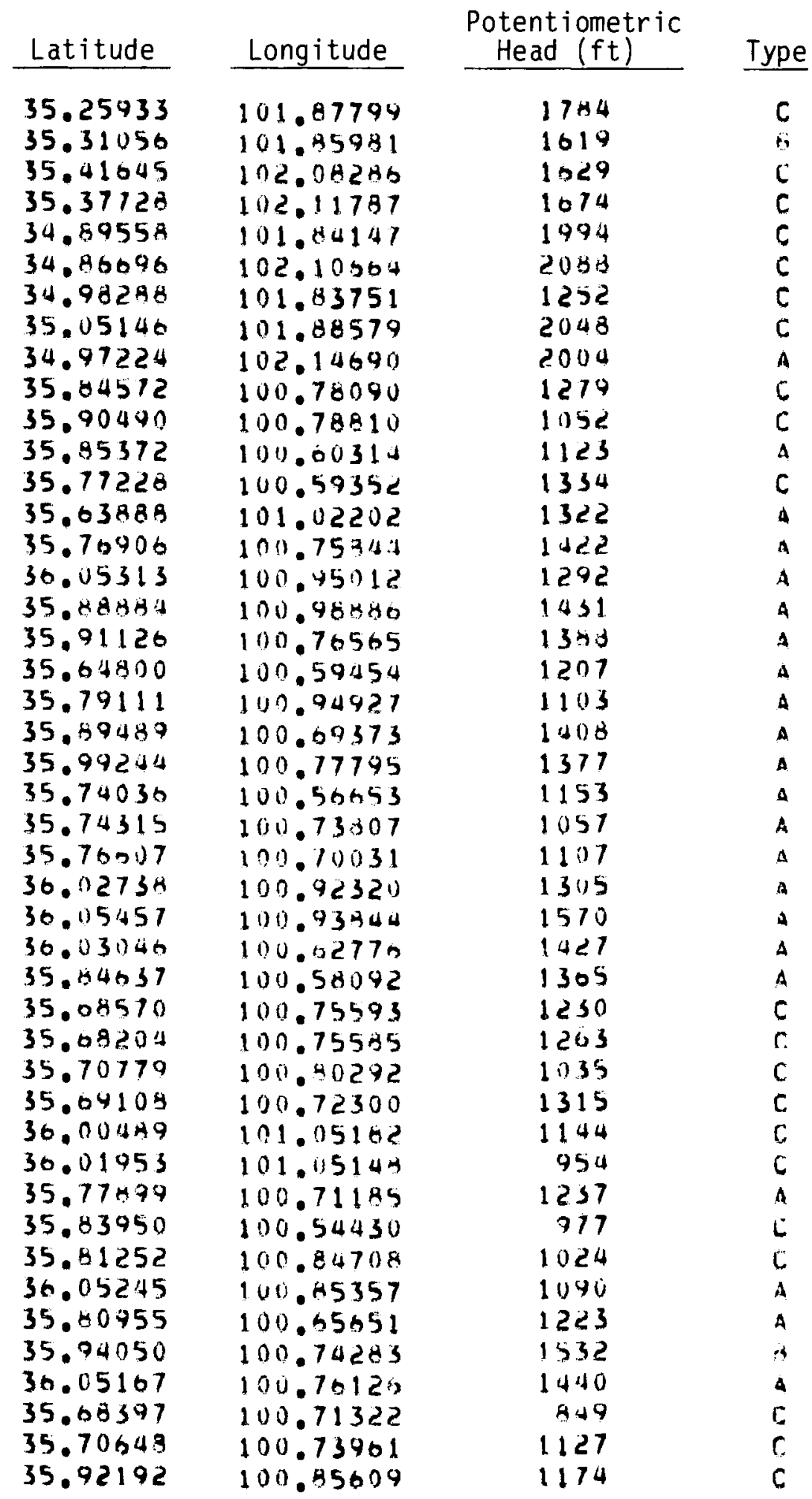


APPENDIX A - continued

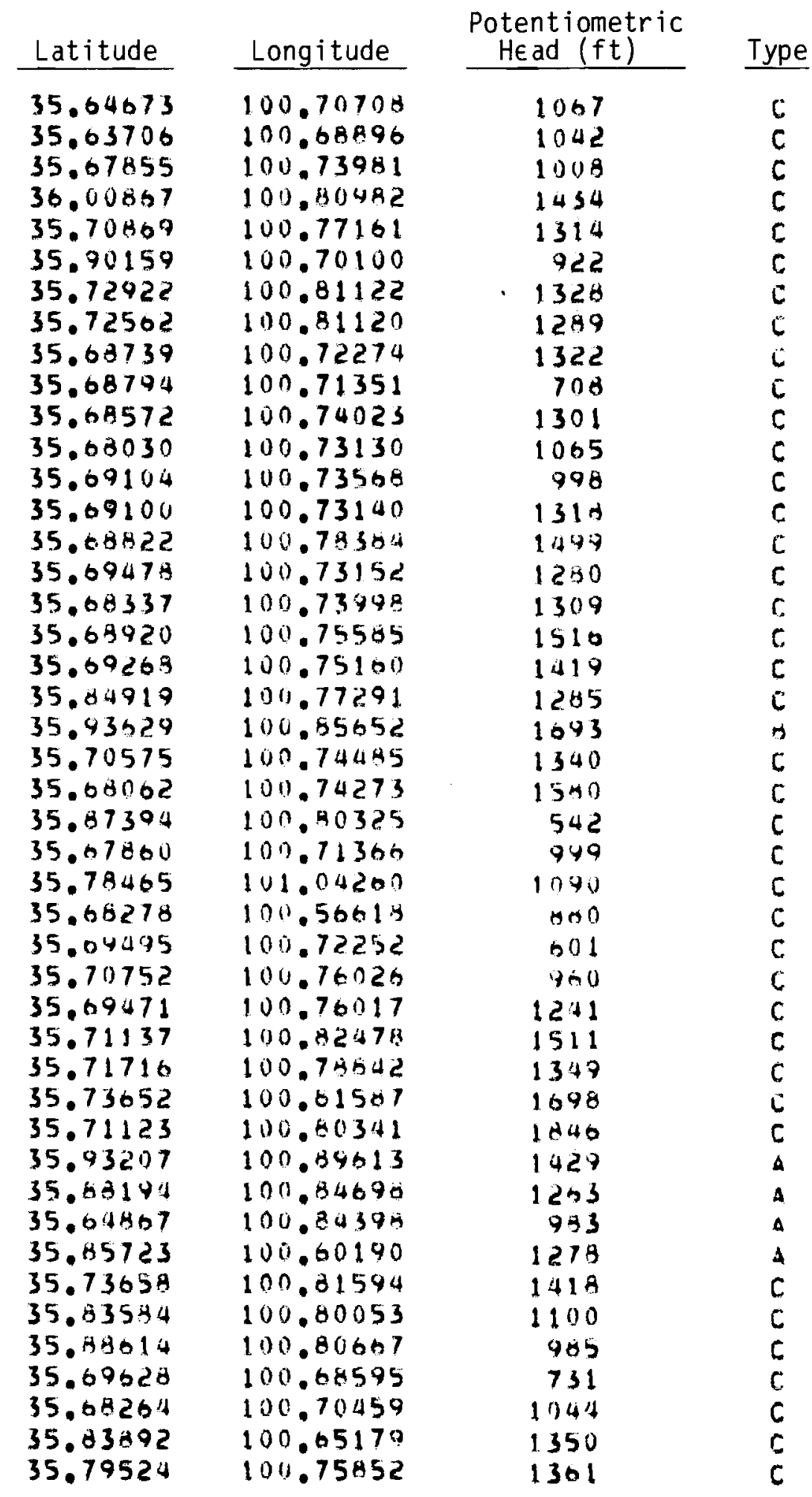




\section{APPENDIX A - continued}

\begin{tabular}{|c|c|c|c|}
\hline Latitude & Longitude & $\begin{array}{l}\text { Potentiometric } \\
\text { Head (ft) }\end{array}$ & Type \\
\hline 36.01340 & 100.57660 & 1160 & C \\
\hline 36.05102 & 100.76115 & 1441 & $\Delta$ \\
\hline 35.52017 & 100.09157 & 1043 & $r$ \\
\hline 35.93912 & 100.74205 & 1557 & $\theta$ \\
\hline 35.84029 & 100.38000 & 1365 & $A$ \\
\hline 35.90140 & 100.09575 & 922 & C \\
\hline 35.63711 & 100.59900 & 1042 & C \\
\hline 35.90961 & 100.00926 & 476 & $c$ \\
\hline 35.72169 & 100.05160 & 1992 & C \\
\hline 35.75471 & 101.04117 & 1000 & A \\
\hline 36.02039 & 100.71537 & 1373 & C \\
\hline 35.00210 & 100.84653 & 1097 & C \\
\hline 35.07807 & 100.69051 & 1320 & $c$ \\
\hline 35.92213 & 100.85507 & 1174 & 4 \\
\hline 35.04707 & 100.70091 & 1007 & C \\
\hline 30.05285 & 100.85371 & 1090 & C \\
\hline 35.87104 & 100.02852 & 1317 & $\Delta$ \\
\hline 35.73903 & 100.75005 & 913 & C \\
\hline 36.15744 & 101.65056 & 1246 & $A$ \\
\hline 36.22072 & 101.70281 & 1157 & a \\
\hline 36.47233 & 101.80942 & 1402 & A \\
\hline 36.47211 & 101.71707 & $102: 1$ & C \\
\hline 30.33493 & 101.96220 & 1815 & c. \\
\hline 30.41353 & 102.00700 & 2337 & C \\
\hline 36.17755 & 101.18107 & 1194 & A \\
\hline 30.45269 & $102.07+27$ & $16+4$ & $c$ \\
\hline 36.49384 & 102.05790 & 2047 & $c$ \\
\hline $36.3687 ?$ & 102.03114 & $12+4$ & $\mathrm{c}$ \\
\hline $36.49 n 97$ & 102.03624 & 2520 & C \\
\hline 34.55616 & 101.90129 & 2360 & $H$ \\
\hline $35.427+8$ & 100.48090 & 1036 & a \\
\hline 35.30982 & 100.13995 & 1332 & A \\
\hline .53531 & 100.50892 & 1240 & C \\
\hline 50538 & 100.37280 & 1328 & A \\
\hline 58620 & 100.38343 & 1609 & 6 \\
\hline 59536 & 100.39045 & 1358 & $A$ \\
\hline 30116 & 100.07344 & 1100 & 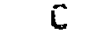 \\
\hline 47302 & 100.43106 & 940 & C \\
\hline 03562 & 101.14980 & 1100 & c \\
\hline 13255 & 101.35767 & 1367 & $r^{4}$ \\
\hline 12109 & 101.41795 & 1047 & $c^{4}$ \\
\hline 34615 & 101.33902 & 2964 & 4 \\
\hline 25780 & 101.24310 & 1501 & $H$ \\
\hline 21572 & 101.42005 & 1360 & C \\
\hline
\end{tabular}


APPENDIX A - continued

\begin{tabular}{|c|c|c|c|}
\hline Lat itude & Long itude & $\begin{array}{l}\text { Potentiometric } \\
\text { Head (ft) } \\
\end{array}$ & Type \\
\hline $\begin{array}{l}35.20928 \\
35.40112 \\
35.24985 \\
34.51754 \\
34.72496 \\
34.63143 \\
34.64046 \\
34.59698\end{array}$ & $\begin{array}{l}101.51457 \\
101.01410 \\
101.41474 \\
102.32644 \\
102.48156 \\
102.15479 \\
102.02041 \\
100.09479\end{array}$ & $\begin{array}{l}1294 \\
1315 \\
1451 \\
2483 \\
2505 \\
1511 \\
2200 \\
1761\end{array}$ & $\begin{array}{l}C \\
0 \\
1 \\
4 \\
+1 \\
C \\
M \\
11\end{array}$ \\
\hline
\end{tabular}


DISTRIBUTION

No. of

Copies

OFFSITE

27 DOE Technical Information Center

R. E. Cunningham

Nuclear Regulatory Commission

7915 Eastern Avenue

Silver Springs, MD 20910

R. Dale Smith

Division of Waste Management Nuclear Regulatory Commission Washington, DC 20555

D. M. Rohrer

Office of Inspection and Envorceilent Nuclear Regulatory Commission Washington, DC 20555

Materials Section Leader

High-Level Waste Licensing Branch

Nuclear Regulatory Commission Washington, DC 20555

W. E. Mott

DOE Division of Environmental Control Technology

Washington, DC 20545

T. A. Dillon

DOE Office of Nuclear Energy

1000 Independence Ave. SW

NE-2, Forrestal

Washington, DC 20585

A. F. Perge

DOE International Programs of Nuclear Energy

NE-75, GTN

Washington, DC 20545
No. of

Copies

2 DOE Terminal Waste Disposal and Remedial Action

NE30, GTN

Washington, DC 20545

ATTN: F. E. Coffman

J. R. Coleman

2 DOE Nuclear Waste Policy Act Project Office

S-10 Forrestal

Washington, DC 20585

ATTN: J. W. Bennett

R. L. Morgan

3 Geologic Repository Division DOE Nuclear Waste Policy Act GTN Project Office

Washington, DC 20545

ATTN: C. R. Cooley, S-10, NE -22

C. H. George, S-10/NE-22

R. Stein

2 DOE Office of Defense Waste and Byproducts Management GTN

Washington, DC 20545

ATTN: J. E. Dieckhoner

G. 0erte1

W. F. Holcomb

Environmental Protection Agency

Office of Radiation Programs

Washington, DC 20460

S. A. Mann

DOE Chicago Operations and

Region

Office

9800 South Cass Avenue

Argonne, IL 60439 
No. of

Copies

J. O. Neff

Department of Energy

Columbus Program Office

505 King Avenue

Columbus, $\mathrm{OH} 43201$

2 DOE Idaho Operations Office

550 2nd Street

Idaho Falls, ID 83401

ATTN: J. P. Hamric

J. B. Whitsett

3 DOE Oak Ridge Operations Office P.0. Box E

Oak Ridge, TN 37830

ATTN: S. W. Ahrends (2)

D. E. Large

3 DOE Savannah River Operations

Office

P.0. Box A

Aiken, SC 29801

ATTN: T. B. Hindman

R. P. Whitfield

W. B. Wilson

3 DOE Albuquerque Operations

Office

P.0. Box 5400

Albiqquerque, NM 87185

ATTN: R. Y. Lowrey (2)

M. H. McF adden

S. G. Harbison

DOE San Francisco Operations

Office

1333 Broadway

0akland, CA 94612

D. L. Vieth

DOE Nevada Operations Office

Las Vegas, NV 89114

2 Environmental Protection Agency

Technological Assessment

Division

(AW-559)

Office of Radiation Programs

Washington, DC 20450
No. of

Copies

11 Battelle Memorial Institute

$505 \mathrm{King}$ Avenue

Columbus, $\mathrm{OH} 43201$

ATTN: A. Brandstetter

B. Rawles

S. J. Basham/D. E. Clark

W. A. Carbiener

W. Cote

S. Goldsmith

W. Harper

W. M. Hewitt

J. F. Kircher

W. J. Madia

W. Pardue

Neville G. W. Cook

Dept. of Materials Science and Mineral Engineering

Hearst Mining Building

University of California

Berkeley, CA 94720

Robert M. Garrells

Dept. of Geologic Sciences

Northwestern University

Evanston, IL 60201

Philip Helmke

1525 Observatory Drive

University of Wisconsin

Madison, WI 53706

Don Langmuir

Dept. of Chemistry and Geochemi stry

Colorado School of Mines

Golden, CO 80401

N. A. Norman

Environmental Sciences Dept.

Bechtel National, Inc.

P.0. Box 3965

San Francisco, CA 94105

F. L. Parker

Dept. of Environimental

Engineering

Vanderbuilt University

Nashville, TN 37235 
No. of

Copies

G. F. Pinder

Dept. of Civil Engineering

Princeton University

Princeton, NJ 08540

H. L. Ragsdale

Dept. of Biology

Emory University

Atlanta, GA 30322

A. J. Soinski

Energy Resources Conservation and Development Commission

1111 Howe Avenue

Sacramento, CA 95825

H. P. Stephens

Sandia Laboratories

P.0. Box 5800

A1buquerque, NM 87115

D. B. Stewart

U.S. Geological Survey

National Center 959

Reston, VA 22092

Robert Williams

Electric Power Research Institute

3412 Hillview Avenue

Palo Alto, CA 94304

P. A. Witherspoon

Earth Sciences Division

Lawrence Berkeley Laboratory

Building 90

Berkeley, CA 94720

2 Sandia National Laboratory

P.0. Box 5800

Albuquerque, NM 87115

ATTN: R. Iman

L. D. Tyler

S. Bair

Stone and Webster Engineering Corporation

P.0. Box 5200

Cherry Hi11, NJ 08034
No. of

Copies

\author{
T. H. Pigford \\ University of California at \\ Berkeley \\ Berkeley, CA 94720 \\ 2 Oak Ridge National Laboratory \\ Oak Ridge, TN 37830 \\ ATTN: E. Oblow \\ S. S. Stow
}

W. G. Sutcliffe

Lawrence Livermore National

Laboratory

P.0. Box 808

Livermore, CA 94550

Los Alamos National Laboratory

Reference Library

P.0. Box 1663

Los Alamos, NM 87544

J. Wilson

Intera Environmental

Consultants, Inc.

11999 Katy Freeway, Suite 610

Houston, TX 77079

A. Brecher

Arthur D. Little, Inc.

Acorn Park

Cambridge, MA 02140

J. Sykes

University of Water 100

Water100, Ontario N2L3G1

B. Pardue

Office of Crystalline Repositury Development

Battelle Memorial Institute

$505 \mathrm{King}$ Avenue

Columbus, $\mathrm{OH} 43201$

\section{ONSITE}

3 DOE Richland Operations Office

J. J. Schreiber (2)

H. E. Ransom 
No. of

Copies

4 Rockwell Hanford Operations

R. J. Gimera (2)

D. D. Wodrich

L. Fitch

IJNC United Nuclear Industries

F. H. Bouse, Document Control

Westinghouse Hanford Company

\section{A. G. Blasewitz}

51 Pacific Northwest Laboratory

L. L. Ames

D. J. Bradley

H. C. Burkholder

T. D. Chikalla/M. R. Kreiter
No. of

Copies

Pacific Northwest Laboratory (contd)

L. L. Clark

C. R. Cole

R. A. Craig

J. L. Devary (25)

D. W. Dragnich/C. E. Elderkin

F. H. Dove

M. G. Foley

C. T.Kincaid

K. M. Krupka

G. L. McVay

R. W. Nelson

R. E. Nightingale/J. H. Jarrett

A. M. Platt

R. J. Serne

J. A. Stottlemyer

R. E. Westerman

Technical Information (5)

Publishing Coordination (2) 